\title{
Ion Transporters and Abiotic Stress Tolerance in Plants
}

\author{
Faïçal Brini and Khaled Masmoudi \\ Plant Protection and Improvement Laboratory, Centre of Biotechnology of Sfax (CBS), University of Sfax, \\ P.O. Box 1177, 3018 Sfax, Tunisia \\ Correspondence should be addressed to Faïçal Brini, faical.brini@cbs.rnrt.tn
}

Received 15 March 2012; Accepted 10 April 2012

Academic Editors: M. Greenwood, T. O’Connor, and M. Sekine

Copyright ( $) 2012$ F. Brini and K. Masmoudi. This is an open access article distributed under the Creative Commons Attribution License, which permits unrestricted use, distribution, and reproduction in any medium, provided the original work is properly cited.

\begin{abstract}
Adaptation of plants to salt stress requires cellular ion homeostasis involving net intracellular $\mathrm{Na}^{+}$and $\mathrm{Cl}^{-}$uptake and subsequent vacuolar compartmentalization without toxic ion accumulation in the cytosol. Sodium ions can enter the cell through several lowand high-affinity $\mathrm{K}^{+}$carriers. Some members of the HKT family function as sodium transporter and contribute to $\mathrm{Na}^{+}$removal from the ascending xylem sap and recirculation from the leaves to the roots via the phloem vasculature. $\mathrm{Na}^{+}$sequestration into the vacuole depends on expression and activity of $\mathrm{Na}^{+} / \mathrm{H}^{+}$antiporter that is driven by electrochemical gradient of protons generated by the vacuolar $\mathrm{H}^{+}$-ATPase and the $\mathrm{H}^{+}$-pyrophosphatase. Sodium extrusion at the root-soil interface is presumed to be of critical importance for the salt tolerance. Thus, a very rapid efflux of $\mathrm{Na}^{+}$from roots must occur to control net rates of influx. The $\mathrm{Na}^{+} / \mathrm{H}^{+}$ antiporter SOS1 localized to the plasma membrane is the only $\mathrm{Na}^{+}$efflux protein from plants characterized so far. In this paper, we analyze available data related to ion transporters and plant abiotic stress responses in order to enhance our understanding about how salinity and other abiotic stresses affect the most fundamental processes of cellular function which have a substantial impact on plant growth development.
\end{abstract}

\section{Introduction}

Agricultural productivity is severely affected by soil salinity. Environmental stress due to salinity is one of the most serious factors limiting the productivity of agricultural crops, most of which are sensitive to the presence of high concentrations of salts in the soil. There are two main components to salinity stress in plants; an initial osmotic stress and a subsequent accumulation of toxic ions which negatively affects cellular metabolism [1]. In addition, it can lead to secondary stresses such as nutritional imbalance and oxidative stress [2]. The $\mathrm{Na}^{+}$cation is chaotropic and predominantly associated with the deleterious effect of salinity, and therefore, most research has focused on this mineral. However, plant adaptation to salt stress also requires appropriate regulation of $\mathrm{Cl}^{-}$homeostasis [3]. Indeed, for species such as soybean, citrus, and grapevine where $\mathrm{Na}^{+}$ is predominantly retained in the roots and stems, $\mathrm{Cl}^{-}$is considered more toxic since this ion is accumulated to high levels in shoot tissues, negatively impacting on essential processes such as photosynthesis. The osmotic component of salinity is caused by excess inorganic ions such as $\mathrm{Na}^{+}$ and $\mathrm{Cl}^{-}$in the environment that decrease the osmotic potential of the soil solution and hence water uptake by the plant root. Uptake of abundantly available $\mathrm{Na}^{+}$and $\mathrm{Cl}^{-}$ therefore, offers a comparatively cheap way to lower the tissue-osmotic potential. To avoid the risk of ion toxicity associated with this strategy, $\mathrm{Na}^{+}$and $\mathrm{Cl}^{-}$are generally compartmentalized in the vacuole and/or in less sensitive tissues. In parallel, adjustment of the cytoplasmic compartment is achieved via production of compatible osmolytes such as, proline, mannitol, sorbitol, and glycine betaine. The latter also acts as antioxidant and thus detoxifies reactive oxygen species (ROS). However, when plants are growing in high salt concentrations, an adequate sequestration of ions in the vacuole can become a limiting factor, especially in the case of glycophytes. In this scenario, plants can accumulate excessive amount of $\mathrm{Na}^{+}$in the cytosol which negatively affects many aspects of cellular physiology. The most abundant inorganic cation in the cytosol is $\mathrm{K}^{+}$, in 
plant as in animal cells. This might be due to the fact that this cation is less chaotropic than $\mathrm{Na}^{+}$, that is, more compatible with protein structure even at high concentrations. The physicochemical similarities between $\mathrm{Na}^{+}$and $\mathrm{K}^{+}$lead to a competition at transport and catalytic sites that normally bind the essential cation $\mathrm{K}^{+}$and maintaining a high cytosolic $\mathrm{K}^{+} / \mathrm{Na}^{+}$ratio is believed to improve salt tolerance $[4,5]$. Oxidative stress is another aspect of salinity stress which is in fact a consequence of salinity-induced osmotic and/or ionic stress [6]. The salt-induced production of ROS such as superoxide radicals $\left(\mathrm{O}^{2-}\right)$, hydrogen peroxide $\left(\mathrm{H}_{2} \mathrm{O}_{2}\right)$, and hydroxyl radicals $(\mathrm{OH})$ has then a severe effect on cellular structure and metabolism negatively [7].

Although considerable progress was made to increase and secure crop yield through conventional breeding, the goal of improving the resistance of crops to abiotic stresses has seen limited success because of the complex, multigenic nature of the traits, and the narrow genetic variation in the gene pools of major crops. Numerous genes and proteins have been shown to affect the tolerance to environmental stress in an array of plant species, which together compose a complex puzzle with a myriad of individual elements and crisscrossing signal transduction pathways. A common theme of tolerance is the adequate control of salt uptake at the root level, regulation of influx into cells, control over long distance transport, and the compartmentation at both cellular and tissue levels $[8,9]$. These processes are mediated by membrane transporters and manipulating the activity of this class of proteins has therefore enormous potential to affect plant performance in saline conditions [10]. Different approaches have been used to identify membrane transporters with putative functions in salt tolerance. Yeast is widely used as host for heterologous expression of plant proteins. Yeast complementation screens led to the isolation of plant transporters such as the vacuolar $\mathrm{Na}^{+} / \mathrm{H}^{+}$antiporter AtNHX1 [11] and the plasma membrane $\mathrm{K}^{+} / \mathrm{Na}^{+}$symporter TaHKT1 [12]. Loss of function mutants in the model system Arabidopsis thaliana helped characterize many membrane transporters including AtHKT1:1 involved in long distance $\mathrm{Na}^{+}$transport [13], the plasma membrane $\mathrm{Na}^{+} / \mathrm{H}^{+}$antiporter SOS1 [14], and the vacuolar pyrophosphatase AtVP1 [15]. It is well established that uptake, efflux, translocation, and compartmentation of toxic ions (mainly $\mathrm{Na}^{+}$and $\mathrm{Cl}^{-}$) provide important bases for salinity tolerance in plants, and hence, a potential avenue to improve crops. However, a lack of understanding regarding the molecular entities and complex interactions of the responsible membrane transport proteins has hindered progress in this respect. The present paper focuses on the main ionic constituents of salinity, $\mathrm{Na}^{+}$and $\mathrm{Cl}^{-}$and also analyses which specific membrane transporters have been shown, or are believed, to be involved in uptake, extrusion, long-distance transport, and compartmentalization of salt at the cellular and tissue level. Subsequently, the paper critically evaluates the reported data to assess which proteins may be particularly suitable as engineering targets to improve crop salt tolerance.

\section{Sodium Uptake from Soil}

The excess of salts in the soil solution poses a challenge to the plant. $\mathrm{Na}^{+}$and other ions taken up by roots are transported to shoots in the transpiration stream, where they accumulate over time [3]. Elevated concentrations of salts are built up in the apoplast and eventually inside the cell, as water evaporates. The accumulation of ions in plant tissues results in progressive damage. These ionic specific stress effects are superimposed on those caused by hyperosmolarity [3]. Whether plants have specific transport systems for lowaffinity $\mathrm{Na}^{+}$uptake from soil remains an open question [16] and the exact mechanisms responsible for root $\mathrm{Na}^{+}$and $\mathrm{Cl}^{-}$ uptake are only partially clear and likely include transporters from several gene families and transport classes.

\subsection{The Role of Nonselective Cation Channels in $\mathrm{Na}^{+}$Uptake.} In the last few years, evidence has been presented supporting the existence of weakly voltage-dependent nonselective cation channels (NSCC) that are the main pathway for $\mathrm{Na}^{+}$entry into the roots, at high soil $\mathrm{NaCl}$ concentrations $[17,18]$. Although there are many candidate genes in the databases that could encode these NSCC channels, their identity remains elusive. Two families of nonselective cation channels, CNGCs (cyclic nucleotide-gated channels) [19], and GLRs (glutamate-activated channels) [20] have been suggested to be candidate NSCC channels (Figure 1) [17]. The inhibition of $\mathrm{Na}^{+}$influx and NSCC currents upon addition of membrane permeable cyclic nucleotide analogues provided correlative evidence for the operation of CNGCs in plants [21], a family of plant channels that in Arabidopsis comprise 20 members [22]. To date, five AtCNGCs have been characterized (AtCNGC1, 2, 3, 4, and 10) [19, 23-25]. Electrophysiological studies have suggested that AtCNGC1 and AtCNGC4 are equally permeable to $\mathrm{K}^{+}$and $\mathrm{Na}^{+}$and when expressed in Xenopus oocytes, they displayed activation by cyclic nucleotides $[19,23]$. AtCNGC2 appears to be selective for $\mathrm{K}^{+}$and to discriminate against $\mathrm{Na}^{+}$[19]. AtCNGC10 rescued $\mathrm{K}^{+}$transport defective mutants of $E$. coli, yeast, and Arabidopsis akt1-1, suggesting that AtCNGC10 mediates the transport of $\mathrm{K}^{+}$into the roots [24]. AtCNGC3 was recently characterized by functional complementation of yeast and by characterization of Arabidopsis T-DNA knockout mutants [25]. AtCNGC3 was primarily expressed in the cortical and epidermal root cells. Growth of the mutant seedlings in toxic $\mathrm{NaCl}$ (and $\mathrm{KCl}$ ) concentrations was improved, suggesting a restricted ion influx in the mutant plants [25]. Ionotropic glutamate receptors (GLRs) are proteins that interact with glutamate and form cation channels with a wide range of permeability's. In Arabidopsis, the family of putative GLRs comprises 20 members [20]. Glutamate-activated $\mathrm{Na}^{+}$and $\mathrm{Ca}^{2+}$ voltage-independent currents were characterized in Arabidopsis roots. Demidchik et al. [20] noted that although the effects of environmental factors on apoplastic glutamate remain unclear, the concentrations of glutamate required for half activation of these channels correlated well with the range of apoplastic glutamate concentrations reported $(0.2-0.5 \mathrm{mM})$, suggesting a role of these channels in $\mathrm{Na}^{+}$ uptake. 


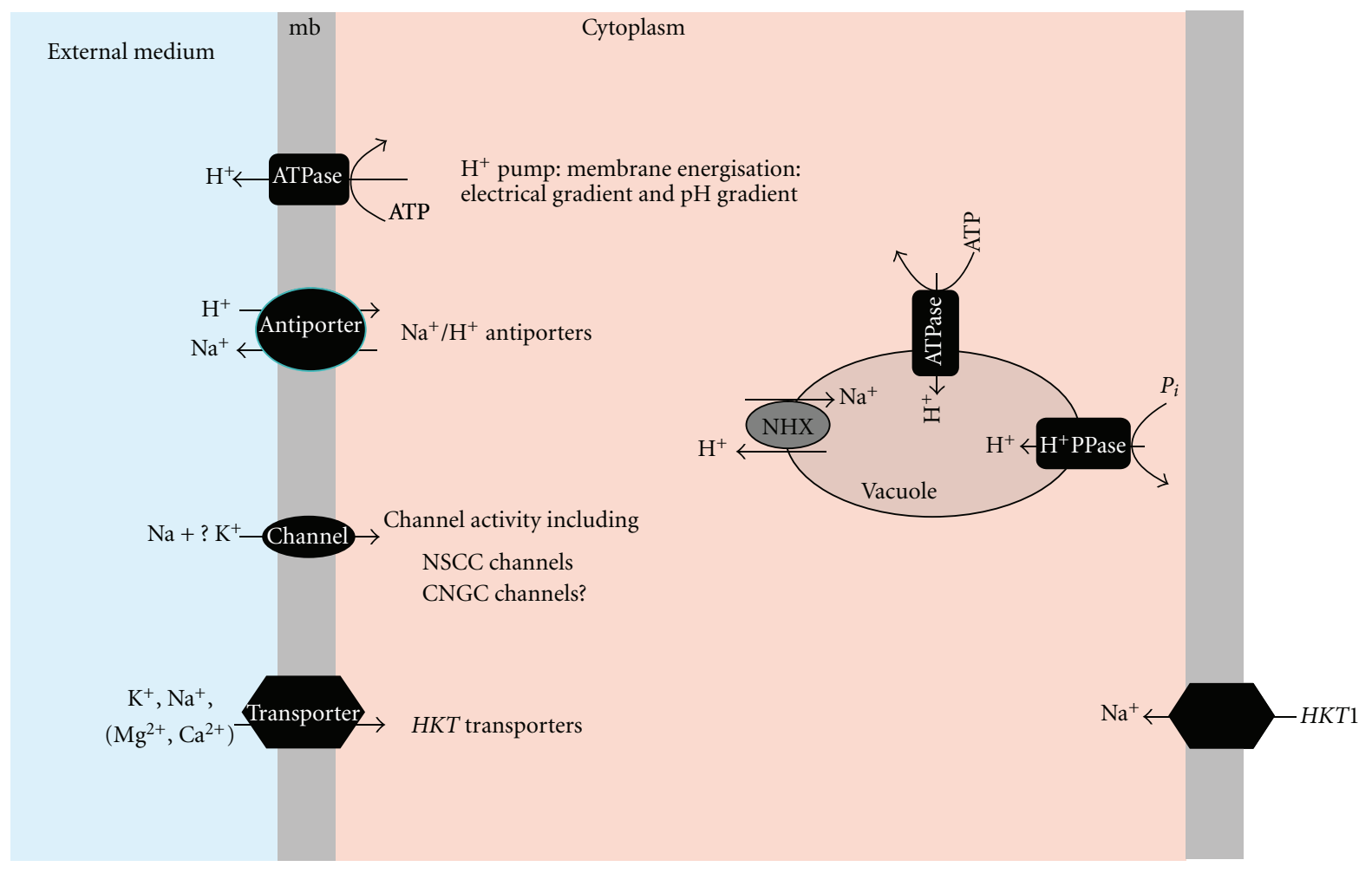

FIGURE 1: The main transport systems identified so far at the plasma membrane.

2.2. Potassium Channels May Contribute to $\mathrm{Na}^{+}$Uptake. Sodium has a strong inhibitory effect on $\mathrm{K}^{+}$uptake by cells, presumably by interfering with transporters in the root plasma membrane such as the Shaker type $\mathrm{K}^{+}$channels (KAT1 and AKT1 form the predominant inward $\mathrm{K}^{+}$conductance observed in plant plasma membranes). Such channels generally have a high $\mathrm{K}^{+} / \mathrm{Na}^{+}$selectivity and were generally regarded not to play a significant role in $\mathrm{Na}^{+}[26,27]$. However, a more recent work suggests that the picture is more complex and there may be ecophysiological variations in this respect. Wang et al. [28] used apharmacological approach to characterize $\mathrm{Na}^{+}$uptake in the halophyte Suaeda maritima and concluded that the low-affinity $\mathrm{Na}^{+}$ uptake pathway in this species resembles an AKT1 channel. Similarly, Kader and Lindbergh [29] provide evidence that $\mathrm{K}^{+}$channels mediate substantial $\mathrm{Na}^{+}$influx in a salt-sensitive rice cultivar but not in a tolerant one. In both cases the conclusions were derived from applying channel blockers and inhibitors which can be notoriously nonspecific, but these findings do suggest that $\mathrm{K}^{+}$channels are potential pathways for root $\mathrm{Na}^{+}$influx. In addition, the study by Wang et al. [28] suggests that basic processes such as $\mathrm{Na}^{+}$ uptake may be considerably different in halophytes and such diversity could be an important contributor to salt tolerance. However, the scarcity in data from halophytes in this respect forms a large hindrance in testing this hypothesis.

\subsection{Carrier-Type Transporters That Mediate $\mathrm{Na}^{+}$Uptake.} $H K T s$ (high affinity potassium transporters) are carriertype proteins that mediate $\mathrm{Na}^{+}$and $\mathrm{K}^{+}$transport (Figure 1)
[30]. Members of the HKT gene family are $\mathrm{Na}^{+}$-specific transporters (although they were initially described as highaffinity $\mathrm{K}^{+}$transporters and hence their name) that mediate either preferential $\mathrm{Na}^{+}$transport or $\mathrm{Na}^{+}-\mathrm{K}^{+}$symport, partly depending on whether the specific transporter has a highly conserved serine (subfamily 1) or glycine (subfamily 2) residue in the first pore loop of the protein and on the extracellular $\mathrm{Na}^{+}-\mathrm{K}^{+}$ratio $[31,32]$. Generally, HKT members of subfamily 1 have a relatively higher $\mathrm{Na}^{+}$-to- $\mathrm{K}^{+}$selectivity than subfamily $2 H K T$ transporters. In Arabidopsis, loss of function of the only $H K T 1 ; 1$ gene encoding a $\mathrm{Na}^{+}$-selective transporter caused the accumulation of $\mathrm{Na}^{+}$in leaves but reduced $\mathrm{Na}^{+}$concentrations in roots, with little effect on the net uptake of $\mathrm{Na}^{+}$by the plant $[13,33,34]$. AtHKT1;1 is preferentially expressed in the vasculature, where it is thought to regulate the $\mathrm{Na}^{+}$distribution between roots and shoots [13, 31-35]. Two complementary functions for AtHKT1;1 have been proposed [36]. The phloem recirculation model posits that $\mathrm{Na}^{+}$is loaded into shoot phloem cells by AtHKT1;1 and then transferred to roots via the downward stream of phloem, preventing $\mathrm{Na}^{+}$over accumulation in shoots (Table 1) [37]. However, there seems to be little (10\% or less) retranslocation of $\mathrm{Na}^{+}$from leaves via the phloem relative to the amount imported in the transpiration stream via the xylem $[17,38,39]$. On the other hand, AtHKT1;1 is generally accepted to mediate the retrieval of $\mathrm{Na}^{+}$from the xylem sap, thereby restricting the amount of $\mathrm{Na}^{+}$reaching the photosynthetic tissues [34, 37-39]. These two $\mathrm{Na}^{+}$transport processes could be functionally linked to achieve basi-petal translocation of $\mathrm{Na}^{+}$because ions that were unloaded by 
TABLE 1: Plant ion transporters involved in salt tolerance identified by functional analysis.

\begin{tabular}{|c|c|c|c|c|c|c|}
\hline Name & $\begin{array}{l}\text { Source } \\
\text { species }\end{array}$ & Gene product & Function & $\begin{array}{l}\text { Identification } \\
\text { method }\end{array}$ & Harbourg species & Reference \\
\hline \multicolumn{7}{|c|}{ Sodium influx } \\
\hline AtHKT1 & A. thaliana & $\mathrm{Na}^{+}$transporter & $\mathrm{Na}^{+} / \mathrm{K}^{+}$homeostasis & Mutation & Arabidopsis & {$[13]$} \\
\hline HKT1 & T. aestivum & $\begin{array}{l}\mathrm{Na}^{+} / \mathrm{K}^{+} \\
\text {transporter }\end{array}$ & $\mathrm{K}^{+} / \mathrm{Na}^{+}$homeostasis & Overexpression & Wheat & {$[31]$} \\
\hline \multicolumn{7}{|c|}{ Sodium efflux } \\
\hline AtSOS1 & A. thaliana & $\begin{array}{l}\text { Plasma membrane } \\
\mathrm{Na}^{+} / \mathrm{H}^{+} \text {antiporter }\end{array}$ & $\mathrm{Na}^{+}$detoxification & Mutation & Arabidopsis overexpression & {$[76]$} \\
\hline TaSOS1 & T. aestivum & $\begin{array}{l}\text { Plasma membrane } \\
\mathrm{Na}^{+} / \mathrm{H}^{+} \text {antiporter }\end{array}$ & $\mathrm{Na}^{+}$detoxification & Mutation & Arabidopsis overexpression & {$[99]$} \\
\hline \multicolumn{7}{|c|}{ Sodium compartmentation } \\
\hline AtNHX1 & A. thaliana & $\begin{array}{l}\text { Vacuolar } \mathrm{Na}^{+} / \mathrm{H}^{+} \\
\text {antiporter }\end{array}$ & $\mathrm{Na}^{+}$vacuolar sequestration & Overexpression & $\begin{array}{l}\text { Arabidopsis, } \\
\text { Cabbage, tomato }\end{array}$ & $\begin{array}{l}{[11]} \\
{[93]}\end{array}$ \\
\hline TNHX1 & T. aestivum & $\begin{array}{l}\text { Vacuolar } \mathrm{Na}^{+} / \mathrm{H}^{+} \\
\text {antiporter }\end{array}$ & $\mathrm{Na}^{+}$vacuolar sequestration & Overexpression & Arabidopsis & {$[96,114]$} \\
\hline$A V P 1$ & A. thaliana & Vacuolar $\mathrm{H}^{+}$-PPase & $\begin{array}{l}\mathrm{H}^{+} \text {transport, vacuolar } \\
\text { acidification }\end{array}$ & Overexpression & Arabidopsis & {$[15]$} \\
\hline TVP1 & T. aestivum & Vacuolar $\mathrm{H}^{+}$-PPase & $\begin{array}{l}\mathrm{H}^{+} \text {transport, vacuolar } \\
\text { acidification }\end{array}$ & Overexpression & Arabidopsis & {$[96,114]$} \\
\hline \multicolumn{7}{|c|}{ Regulatory genes } \\
\hline SOS2 & A. thaliana & $\begin{array}{l}\text { Serine/threonine } \\
\text { Protein kinase }\end{array}$ & SOS1 regulator & Mutation & Arabidopsis & {$[87]$} \\
\hline SOS3 & A. thaliana & $\begin{array}{l}\mathrm{Ca}^{++} \text {binding } \\
\text { protein }\end{array}$ & $\mathrm{Ca}^{++}$sensor/SOS2 activator & Mutation & Arabidopsis & {$[81]$} \\
\hline
\end{tabular}

xylem parenchyma cells might be transported into the phloem via symplastic diffusion [36]. Engineered expression of AtHKT1; 1 in the root pericycle of Arabidopsis enhanced inward $\mathrm{Na}^{+}$-transport in the targeted cells, reduced rootto-shoot transfer of $\mathrm{Na}^{+}$, and improved salt tolerance [40]. However, it remains unclear whether the reduced activity of AtHKT1;1 was the sole basis for enhanced tolerance or if there were other processes that could also contribute to salt tolerance linked to enhanced $\mathrm{Na}^{+}$accumulation such as improved capacity for $\mathrm{Na}^{+}$sequestration in vacuoles [41]. Similar studies in cereals have shown that natural variation in the activity or expression of HKT transporters may be a genetic resource for enhanced $\mathrm{NaCl}$ tolerance. In rice, two of the nine members, OsHKT2;1 and OsHKT2;2, are expressed in roots amongst other tissues [42]. OsHKT2;2 catalyses $\mathrm{Na}^{+}$-dependent $\mathrm{K}^{+}$uptake [43]. OsHKT2;1 has been shown to catalyse high-affinity $\mathrm{Na}^{+}$uptake into roots under $\mathrm{K}^{+}$-starvation conditions, and it appears that $\mathrm{Na}^{+}$can partially replace the function of $\mathrm{K}^{+}$under such conditions [43]. OsHKT2;1 has been shown to catalyse high-affinity $\mathrm{Na}^{+}$uptake into roots under $\mathrm{K}^{+}$-starvation conditions, and it appears that $\mathrm{Na}^{+}$can partially replace the function of $\mathrm{K}^{+}$under such conditions [43]. Expression of OsHKT2;1 is localized to the root epidermis, cortical cells, and vascular tissues of both roots and leaves [43-45], and expression patterns in roots were found to be different in salt-tolerant and sensitive varieties in response to $\mathrm{NaCl}$ stress [44]. Loss of function mutants in OsHKT2;1 shows reduced growth in low $\mathrm{K}^{+}$conditions and accumulated less $\mathrm{Na}^{+}$
[43]. Thus, it appears that OsHKT2;1 augments monovalent cation uptake by providing high-affinity $\mathrm{Na}^{+}$uptake in $\mathrm{K}^{+}$deficient conditions. However, OsHKT2;1 relevance in $\mathrm{Na}^{+}$uptake during salinity stress may be limited since it has a micromolar affinity for $\mathrm{Na}^{+}$, and its activity is rapidly downregulated at higher ambient concentrations of $\mathrm{Na}^{+}$. Similar high-affinity $\mathrm{Na}^{+}$uptake was observed in $\mathrm{K}^{+}$-starved barley roots. However, when heterologously expressed in yeast, $\mathrm{H} v H K T 2 ; 1$ was shown to mediate $\mathrm{Na}^{+}$ ( or $\mathrm{K}^{+}$) uniport, $\mathrm{Na}^{+}-\mathrm{K}^{+}$symport, or a combination of both, depending on the construct from which the transporter was expressed $[30,46]$. These characteristics suggest that the $H K T$ transporters are potentially of importance in the regulation of $\mathrm{Na}^{+}$influx into roots. Several QTLs responsible for variation of $\mathrm{K}^{+}$and $\mathrm{Na}^{+}$content were mapped to $H K T$ family genes. QTLs analyses showed that greater shoot $\mathrm{K}^{+}$ content of the relatively salt-tolerant rice cultivar Nona Bokra cosegregated with the presence of an allelic variant of SKC1 (shoot $\mathrm{K}^{+}$content) with greater activity relative to that of the salt-sensitive Koshihikari variety [47]. SKC1 (renamed OsHKT1;5) is a plasma membrane $\mathrm{K}^{+}$-independent, $\mathrm{Na}^{+}$selective transporter that is preferentially expressed in the parenchyma cells surrounding xylem vessels. The greater $\mathrm{Na}^{+}$ concentration in the xylem sap and leaves of the salt-sensitive variety would be a consequence of a weaker SKC1 allele and reduced $\mathrm{Na}^{+}$reabsorption from the xylem. Quantitative genetic analyses in wheat have also led to the identification of two loci, Nax1 and Nax2, which reduced $\mathrm{Na}^{+}$accumulation in the leaf blade by excluding $\mathrm{Na}^{+}$from the xylem by two 
different mechanisms [38]. The process controlled by Nax2 was confined to the roots and had the effect of reducing the transport of $\mathrm{Na}^{+}$from root to shoot, presumably by improved discrimination between $\mathrm{Na}^{+}$and $\mathrm{K}^{+}$at the point of xylem loading. The Naxl locus enhanced the retention of $\mathrm{Na}^{+}$in the leaf sheath, thus restricting further passage to the leaf blade [38]. High-resolution mapping and sequencing analyses of known $\mathrm{Na}^{+}$transporter genes have suggested that the Nax1 and Nax2 loci are attributable to polymorphisms in wheat $H K T$ genes encoding proteins of the subfamily 1 with preferred $\mathrm{Na}^{+}$transport $[48,49]$. These results strongly indicate that $\mathrm{Na}^{+}$exclusion from the transpiration stream may be an important mechanism in the salt tolerance of cereals, similar to many other plant species [17]. It should be pointed out, however, that most studies concerning QTL analysis for salt tolerance are based in $\mathrm{Na}^{+}$and/or $\mathrm{K}^{+}$content in tissues or organs and not directly in salt tolerance. Often, higher $\mathrm{Na}^{+} / \mathrm{K}^{+}$ratios are regarded as determinants of salt tolerance itself without considering any other agronomical or physiological traits. In fact, the SKC QTL of rice did not show a significant correlation coefficient with survival to salt stress [50]. A clear difference should be made between QTLs responsible of ionic balance and QTLs for salt tolerance. In addition to HKTs, other carriers have been implicated in $\mathrm{Na}^{+}$uptake. Some members of the high-affinity $\mathrm{K}^{+}$ uptake transporter family $H A K / K U P / K T$ may transport $\mathrm{Na}^{+}$ with low affinity in the presence of high $\mathrm{Na}^{+}: \mathrm{K}^{+}$ratios [51]. Furthermore, yeast expression studies revealed that the normal function of $H A K / K U P / K T s$, high-affinity $\mathrm{K}^{+}$uptake, is competitively inhibited by $\mathrm{Na}^{+}$, pointing to a shared transport pathway of the two monovalent cations $[52,53]$. Several studies have shown substantial transcriptional regulation of HAK/KUP/KT isoforms by salt stress [54-56]. For example, Su et al. [57] observed that the expression of HAKs in Mesembryanthemum crystallinum was upregulated during salt stress and $\mathrm{K}^{+}$-starved conditions. However, whether this result and those for other HAKs relate to a potential role in $\mathrm{Na}^{+}$ uptake or augmentation of $\mathrm{K}^{+}$uptake during salinity stress remains to be established. The low-affinity cation transporter LCT1 from wheat functions as nonselective cation carrier conducting $\mathrm{K}^{+}, \mathrm{Rb}^{+}, \mathrm{Na}^{+}$, and $\mathrm{Ca}^{2+}$ transport in yeast [58, 59]. Expression of $L C T 1$ in yeast leads to an increase in cation influx and hypersensitivity to $\mathrm{Na}^{+}[60]$. Addition of external $\mathrm{Ca}^{2+}$ was found to reduce $\mathrm{Na}^{+}$influx and sensitivity, but the cation profile of the influx caused by LCT1 resembled that of endogenous ion transport in yeast, suggesting that LCT1 might be stimulating the ion transporters already present [60].

2.4. Transporters Involved in $\mathrm{Cl}^{-}$Uptake. Chloride $\left(\mathrm{Cl}^{-}\right)$is a major osmotically active solute in the vacuole involved in both turgor and osmoregulation processes [61], with implications for the proper development of plants [62]. Despite its importance in plant biology, $\mathrm{Cl}^{-}$is one of the less studied essential nutrients at the physiological and molecular levels. In contrast to $\mathrm{Na}^{+}, \mathrm{Cl}^{-}$uptake in most conditions must be energized, but although there is a substantial amount of information regarding $\mathrm{K}^{+}$and $\mathrm{Na}^{+}$transport in plants, very little is clear about the molecular mechanisms behind the substantial $\mathrm{Cl}^{-}$influx that results from salinization [9]. Genes and proteins involved in $\mathrm{Cl}^{-}$transport have been very poorly studied in plants. The attention has been mainly focused on the voltage-dependent $\mathrm{Cl}^{-}$channel $C L C$ family [63-65]. Phylogenetic and functional analyses have shown that plant CLC genes encode anion channels and active $\mathrm{Cl}^{-} / \mathrm{H}^{+}$antiporters localized in endosomal compartments, which are involved in $\mathrm{NO}^{3-}$ compartmentalization [66] and $\mathrm{pH}$ regulation in the trans-Golgi system [67]. Although the transcript abundance of several CLCs is affected by salinity [68], they are unlikely to contribute to root $\mathrm{Cl}^{-}$ uptake: Firstly, plant CLCs have only been detected at endomembranes which appear to exclude a role in $\mathrm{Cl}^{-}$ uptake and secondly the thermodynamics of $\mathrm{Cl}^{-}$uptake role out passive-channel-type mechanisms. A second class of potential $\mathrm{Cl}^{-}$transporters is formed by the cation chloride cotransporters (CCCs) encoding one gene in Arabidopsis and two genes in rice. The Arabidopsis thaliana cation$\mathrm{Cl}^{-}$cotransporters (AtCCCs), expressed in root and shoot tissues, mediate the coordinated symport of $\mathrm{K}^{+}, \mathrm{Na}^{+}$, and $\mathrm{Cl}^{-}$and have been postulated to participate in the longdistance transport of $\mathrm{Cl}^{-}$[62]. Loss of function of AtCCC in Arabidopsis led to a changed root: shoot $\mathrm{Cl}^{-}$ratio but also to a large increase in net $\mathrm{Cl}^{-}$uptake arguing against a role of AtCCC in the uptake of this ion [62]. More recently, the Arabidopsis slow anion channel associated 1 (AtSLAC1) gene was shown to encode for the guard cell plasma membrane S-type anion channel involved in stomatal closure $[69,70]$. Another member of this family, AtSLAH1, is expressed in the root vasculature suggesting a potential involvement in the long-distant transport of anions [69].

\section{Transporters Involved in Salt Efflux}

It is essential that plants possess adequate efflux systems to remove potentially dangerous ions such as $\mathrm{Na}^{+}$from the cytosol. Inevitably, the mechanisms to extrude $\mathrm{Na}^{+}$ into the apoplast or vacuole have to be energized which typically occurs via $\mathrm{H}^{+}$-coupled antiport $[5,71]$, whereas those for $\mathrm{Cl}^{-}$may be (partially) passive. Early studies on tonoplast antiporters showed significant upregulation of their pumping capacity after plant exposure to salt [72, 73]. In the plasma membrane too, evidence for $\mathrm{H}^{+}: \mathrm{Na}^{+}$ antiporters was obtained underlining the relevance of such systems to plant salt tolerance [74]. Data dealing with $\mathrm{Cl}^{-}$ efflux are scarce: using compartmental flux analysis, Britto and Kronzucker [75] showed large $\mathrm{Cl}^{-}$efflux when plants were exposed to $100 \mathrm{mM} \mathrm{NaCl}$. Just as is the case for $\mathrm{Na}^{+}$, the majority (up to $90 \%$ ) of $\mathrm{Cl}^{-}$that entered the symplast was quickly removed. Although some of the $\mathrm{Cl}^{-}$efflux could theoretically be mediated by anion channels, no data are available regarding the mechanistic details or regarding the identity of the proteins involved.

3.1. $\mathrm{Na}^{+}$Efflux Mechanisms at the Plasma Membrane. Comparisons of unidirectional $\mathrm{Na}^{+}$fluxes and rates of net accumulation of $\mathrm{Na}^{+}$in roots indicate that $70-95 \%$ of the 
$\mathrm{Na}^{+}$fluxed into the root symplast is extruded back to the apoplast, and that small differences in $\mathrm{Na}^{+}$exclusion capacity lead to major changes in the net accumulation of $\mathrm{Na}^{+}$[17]. In Arabidopsis, the plasma membrane $\mathrm{Na}^{+} / \mathrm{H}^{+}$exchanger SOS1 (Salt Overlay Sensitive) facilitates $\mathrm{Na}^{+}$homeostasis by extruding the ion from root epidermal cells at the root-soil interface (Table 1, Figure 1) [76, 77]. SOS1 is preferentially expressed in xylem parenchyma cells, and analyses of the $\mathrm{Na}^{+}$ root/shoot partitioning in roots of sos 1 plants under different salt regimes indicate that SOS1 participates in the redistribution of $\mathrm{Na}^{+}$between the root and shoot, likely working in concert with AtHKT1;1 at the plasma membrane of xylem parenchyma cells $[34,36,76,78]$. Additional evidence of the involvement of SOS1 in long-distance $\mathrm{Na}^{+}$transport has been produced recently in the halophytic Arabidopsis relative Thellungiella salsuginea (a.k.a. T. halophila) and in tomato $[79,80]$. Lower net $\mathrm{Na}^{+}$flux was observed in the xylem sap of tomato plants with suppressed SOS1 activity [80]. Downregulation of ThSOS1 in Thellungiella increased $\mathrm{Na}^{+}$accumulation in the root tip and in the stele. Maximal $\mathrm{Na}^{+}$accumulation, concomitant with a decrease in the $\mathrm{K}^{+}$ content, was found in the root xylem parenchyma. These cells presented a $\mathrm{Na}^{+}-\mathrm{K}^{+}$ratio more than 12 times higher than equivalent cells in wild-type plants. Reduced or abolished activity of SOS1 interferes with $\mathrm{K}^{+}$nutrition and longdistance transport [80]. Mutations in rice and Arabidopsis $H K T \mathrm{Na}^{+}$transporters also reduce $\mathrm{K}^{+}$accumulation in shoots during salt exposure $[34,47]$. The activity of the SOS1 exchanger is regulated through protein phosphorylation by the SOS2-SOS3 kinase complex in Arabidopsis (Table 1) $[77,81]$. SOS2/CIPK24 is a serine/threonine protein kinase of the $S n R K 3 / C I P K$ family. SOS3/CBL4 is a myristoylated membrane bound $\mathrm{Ca}^{2+}$ sensor belonging to the recoveringlike family of $S C a B P s / C B L s$. Upon $\mathrm{Ca}^{2+}$ binding, SOS3 binds to and enhances the protein kinase activity of SOS2 [82]. Besides activating SOS2, SOS3 was shown to recruit SOS2 to the plasma membrane to facilitate interaction with SOS1 [81]. SOS2 also interacts with $S C a B P 8 / C B L 10$ to form an alternative protein kinase complex that regulates SOS1 at the plasma membrane [83]. SOS2 has recently been shown to phosphorylate $S C a B P 8 / C B L 10$ at its C-terminus [84], thus adding a new layer of regulation to $\mathrm{CBL}$ proteins besides $\mathrm{Ca}^{2+}$ binding and fatty acyl modifications [85]. This phosphorylation was induced by salt stress, occurred at the membrane, stabilized the SCABP8-SOS2 interaction, and enhanced plasma membrane $\mathrm{Na}^{+} / \mathrm{H}^{+}$exchange activity [84]. Surprisingly, interaction of SOS2/CIPK24 with $S C a B P 8 / C B L 10$ may also result in localization of the kinase complex at the vacuolar membrane where it mediates salt tolerance by regulating the accumulation of $\mathrm{Na}^{+}$in shoot tissues by an as yet undefined mechanism that may involve regulation of the $\mathrm{Na}^{+} / \mathrm{H}^{+}$exchange at the tonoplast $[86,87]$. Regulation of the tonoplast $V$-ATPase by SOS 2 in the absence of CBL proteins has also been reported [88]. Presumably, the posttranslational modifications of $S C a B P 8 / C B L 10$ or the interaction of combinatorial protein kinase complexes with specific targets in different cellular membranes may ultimately define the localization of the protein kinase in vivo.
3.2. Sodium Compartmentation: The Vacuolar $\mathrm{Na}^{+} / \mathrm{H}^{+}$ Antiporter and the $H^{+}$Pump. The compartmentation of $\mathrm{Na}^{+}$ions into vacuoles provides an efficient mechanism to avert the toxic effects of $\mathrm{Na}^{+}$in the cytosol. The transport of $\mathrm{Na}^{+}$into the vacuoles is mediated by cation $/ \mathrm{H}^{+}$ antiporters that are driven by the electrochemical gradient of protons generated by the vacuolar $\mathrm{H}^{+}$-translocating enzymes, the $\mathrm{H}^{+}$ATPases and the $\mathrm{H}^{+}$pyrophosphatase $\left(\mathrm{H}^{+}\right.$-PPase) (Table 1, Figure 1). Although the activity of these cation $/ \mathrm{H}^{+}$antiporters was demonstrated more than 20 years ago [72], their molecular characterization was only possible after the Arabidopsis genome-sequencing project. $\mathrm{Na}^{+}$compartmentation in the vacuole occurs in all tissues and is an important mechanism for osmotic adjustment and $\mathrm{Na}^{+}$detoxification in the cytosol. There are eight $N H X$ gene family members in Arabidopsis [89], and the functions of AtNHX1, 4, 7 and 8 have been studied. AtNHX7 is also known as AtSOS1 and AtNHX8 has been shown to be a $\mathrm{Li}^{+} / \mathrm{H}^{+}$antiporter [90], although the biological relevance of $\mathrm{Li}^{+}$transport remains obscure. AtNHX4 is localized to the vacuole and might function in concert with AtNHX1 (Table 1) [91]. Several reports indicate that constitutive overexpression of the vacuolar transporters increases the salt tolerance of a variety or species. Constitutive overexpression of the Arabidopsis vacuolar $\mathrm{Na}^{+} / \mathrm{H}^{+}$antiporter, AtNHX1, appears to increase salinity tolerance significantly in yeast [92], Arabidopsis [11], tomato [93], Brassica napus [94], and cotton [95]. Similarly, constitutive overexpression of various cereal homologs has been reported to improve the salinity tolerance of Arabidopsis [96], rice [97, 98], wheat [99], and barley [100]. The overexpression of NHX1 appears to increase the capacity of the plant to regulate cytoplasmic and vacuolar $\mathrm{pH}[101,102]$. The cation selectivity is regulated by a luminal C-terminus [103]. The overexpression of NHX1 in Arabidopsis led to a small increase in shoot $\mathrm{Na}^{+}$accumulation [11], possibly allowing the cells to maintain a favourable osmotic balance, yet maintaining low cytoplasmic $\mathrm{Na}^{+}$levels due to sequestration of the $\mathrm{Na}^{+}$within the vacuole. The $n h x 1$ mutant had significantly lower $\mathrm{Na}^{+} / \mathrm{H}^{+}$and $\mathrm{K}^{+} / \mathrm{H}^{+}$exchange capabilities in isolated vacuoles, fewer large epidermal cells, and less overall leaf area, indicating that NHX1 also plays a developmental role [104]. Overexpression and knockout of the NHX1 gene in Arabidopsis have been shown to significantly and differentially alter the expression of a large number of genes involved in the response to salt stress, indicating that Arabidopsis can respond to a change in one $\mathrm{Na}^{+}$transporter by regulating other genes [105, 106]. Other members of the NHX family are also capable of moving $\mathrm{Na}^{+}$. Yokoi et al. [89] reported that AtNHX2 and AtNHX5 could be important salt-tolerant determinants and observed that AtNHX2 has a major function in vacuolar $\mathrm{Na}^{+}$sequestration. $\mathrm{H}^{+}$pumps in the plasma membrane and tonoplast energize solute transport necessary to compartmentalize cytotoxic ions away from the cytoplasm and to facilitate the function of ions as signal determinants [107-109]. That is these pumps provide the driving force $\left(\mathrm{H}^{+}\right.$electrochemical potential) for secondary active transport and function to establish 
membrane potential gradients that facilitate electrophoretic ion flux. The plasma membrane localized $\mathrm{H}^{+}$pump is a $\mathrm{P}$ type ATPase and is primarily responsible for the large $\mathrm{pH}$ and membrane potential gradient across this membrane [109]. A vacuolar type $\mathrm{H}^{+}$-ATPase and $\mathrm{H}^{+}$-PPase generate the $\Delta \mathrm{pH}$ and membrane potential across the tonoplast $[108,110]$. The activity of these $\mathrm{H}^{+}$pumps is increased by salt treatment, and induced gene expression may account for some of the upregulation $[108,111]$. The $\mathrm{H}^{+}$-PPases are considered to form a multigene family. Two cDNA clones (OVP1 and OVP2) encoding vacuolar $\mathrm{H}^{+}$-PPases isolated from rice were reported [112]. Indeed, there are two genes in Arabidopsis annotated as inorganic pyrophosphatase $\mathrm{H}^{+}$-PPase (AVP1, $A V P 3)$ and a third loci encoding a pyrophosphatase like $(A V P 2=A V P L 1)$, more than five isoforms in rice, and at least three isoforms in barley $[107,113]$.

It has been previously demonstrated that overexpression of the $\mathrm{H}^{+}$-PPase AVP1 increases salinity tolerance and $\mathrm{Na}^{+}$ accumulation in Arabidopsis [15]. The vacuolar $\mathrm{Na}^{+}$levels of the transformants were found to be higher than those of wild-type plants, indicating that overexpression of AVP1 led to increased activity of the $\mathrm{Na}^{+} / \mathrm{H}^{+}$antiporter. Functional characterization of wheat $\mathrm{Na}^{+} / \mathrm{H}^{+}$antiporter TNHX1 and vacuolar pyrophosphatase TVP1 was reported by Brini et al. [114]. Transgenic Arabidopsis lines overexpressing TNHX1 or TVP1 are much more resistant to high concentrations of $\mathrm{NaCl}$ and to water deprivation than the wild-type plants. These transgenic plants grow well in the presence of $200 \mathrm{mM} \mathrm{NaCl}$ and also under a water-deprivation regime, while wild-type plants exhibit chlorosis and growth inhibition [96]. In barley, expression of the $\mathrm{H}^{+}$-PPase $H V P 1$, and the vacuolar $\mathrm{Na}^{+} / \mathrm{H}^{+}$antiporter $N H X 1$, was similarly upregulated by salt stress [100] and is regulated by ABA, auxin, and gibberellin [115]. The simultaneous expression of NHX and AVP genes in rice was found to increase salinity tolerance to a greater extent than expression of the genes individually [98]. The overexpression of AVP1 also appears to increase growth rates of plants due to an interaction with the auxin transporter PIN1, which increases auxin transport resulting in more robust plants which are better able to survive stress conditions $[24,116]$.

\subsection{Role of $\mathrm{Cl}^{-}$Channels in Vacuolar $\mathrm{Cl}^{-}$Compartmentation.} In addition to $\mathrm{Na}^{+}, \mathrm{Cl}^{-}$compartmentation is also important for salt tolerance, as elevated levels of $\mathrm{Cl}^{-}$in the cytosol may be harmful, particularly in the case of citrus crops [117]. Since the vacuole is moderately positive with reference to the cytoplasm, part of the vacuolar $\mathrm{Cl}^{-}$sequestration could proceed through ion channels, and several voltage-gated anion channels of the CLC family have been detected in the tonoplast of various species. In Arabidopsis, CLCa was recently shown to function primarily as a $\mathrm{H}^{+}$-coupled antiporter to drive vacuolar nitrate accumulation [66], whereas $C L C c$ may also be involved in $\mathrm{NO}^{3-}$ homeostasis rather than vacuolar $\mathrm{Cl}^{-}$sequestration. However, $C L C$ transcription has been found to respond to salinity: In rice, OsCLCa was significantly upregulated in salt-sensitive cultivars in response to salinity stress and $O s C L C c$, which is expressed in both leaves and roots, showed transcript reduction in the chloride accumulating salt-sensitive IR29 while transient induction occurred in the chloride excluding variety Pokkali [118]. Diédhiou and Golldack [68] showed a coordinated regulation of anion and cation homeostasis in salt-treated rice and suggested a function for $O s C L C c$ in osmotic adjustment at high salinity. Nakamura et al. [119] showed that the same CLC channels partially complimented the yeast gef1 mutant which lacks the yeast $C L C$ channel. In conjunction, these findings suggest that $C L C$-type anion channels are important in mediating $\mathrm{Cl}^{-}$sequestration in vacuole.

\section{Long-Distance Transport of $\mathbf{N a}^{+}$}

An important issue in salt stress physiology is $\mathrm{Na}^{+}$translocation from the root to the shoot $[120,121]$. Physiological evidence suggests that halophytes and salt-resistant glycophytes actively transport $\mathrm{Na}^{+}$from the root to the shoot, whereas salt-sensitive glycophytes appear to limit $\mathrm{Na}^{+}$entry into the transpirational stream to prevent $\mathrm{Na}^{+}$accumulation in the shoot $[120,121]$. The transporter(s) responsible for $\mathrm{Na}^{+}$transport to and from the xylem vessels are not known, although plasma membrane $\mathrm{Na}^{+} / \mathrm{H}^{+}$antiporters have been proposed to fulfil this role $[111,122]$. It also is not known which cell layer(s) might be critical for controlling the extent of $\mathrm{Na}^{+}$entry or exit from the xylem. The plasma membrane antiporter SOS1 is expressed in root parenchyma and in Arabidopsis impacts on $\mathrm{Na}^{+}$loading into the xylem sap during moderate salt stress [76]. However, its exact function may depend on the severity of the salinity stress and includes removal of $\mathrm{Na}^{+}$from the xylem stream when salt stress is excessive. In Arabidopsis, loss-of-function mutations in the HKT1 gene lead to overaccumulation of $\mathrm{Na}^{+}$in shoots and rendered the plant $\mathrm{Na}^{+}$hypersensitive $[37,123]$. RNA in situ hybridizations showed that HKT1 is expressed mainly in leaf phloem tissues and mediates $\mathrm{Na}^{+}$loading into the phloem vessels. In addition, HKT1 may be involved in $\mathrm{Na}^{+}$ unloading from the phloem sap in roots thus providing a mechanism for $\mathrm{Na}^{+}$retranslocation from shoot to root [37]. In rice, OsHKT1;5 is a plasma membrane $\mathrm{Na}^{+}$transporter expressed in xylem parenchyma cells that retrieves $\mathrm{Na}^{+}$from the xylem sap [47]. Genetic analysis revealed an important $\mathrm{K}^{+}$-homeostasis QTL called SKC1 [50]. The SKC1 gene was cloned and found to be OsHKT1;5 [50]. Heterologous expression revealed that $O s H K T 1 ; 5$ is a $\mathrm{Na}^{+}$transporter, and whole plant analysis indicated that it functions in the root xylem parenchyma to retrieve $\mathrm{Na}^{+}$from the xylem stream, thereby reducing $\mathrm{Na}^{+}$accumulation in the shoot [50]. Flux analysis of a salt-tolerant durum wheat landrace, line 149, revealed that $\mathrm{Na}^{+}$exclusion in this line is underpinned by the individual traits of decreased $\mathrm{Na}^{+}$transfer to the shoot and increased $\mathrm{Na}^{+}$retrieval to the leaf sheath tissue [124]. Nax1 and Nax2, two previously mapped QTLs that have been linked to salinity tolerance in line149 were found to control the two transport traits [38]. The Nax2 locus coincided with a $\mathrm{Na}^{+}$transporter related to OsHKT1;5 in rice, and this gene was shown to be responsible for removal of $\mathrm{Na}^{+}$from the xylem in the roots [49]. Members of the $\mathrm{H}^{+}$: monovalent 
cation exchanger family $(C H X)$ are also likely to contribute to $\mathrm{Na}^{+}$translocation. AtCHX21 is mainly expressed in the root endodermis, and loss of function in this gene reduced levels of $\mathrm{Na}^{+}$in the xylem sap without affecting phloem $\mathrm{Na}^{+}$concentrations [125]. In rice, salt-induced expression of OsCHX11 in roots was cultivar dependant and higher in a tolerant cultivar [126]. The differential expression correlated with a higher $\mathrm{K}^{+} / \mathrm{Na}^{+}$ratio in the tolerant cultivar suggesting that $C H X 11$ may be involved in long-distance transport of $\mathrm{Na}^{+}$and/or $\mathrm{K}^{+}$.

\section{Engineering Plant Salinity Tolerance}

Currently, a large number of potential gene targets are available to manipulate salt tolerance. This number has drastically increased through the many large scale transcriptomic studies over the past decade, but in many cases the validity of the reported findings has yet to be established. For the various processes that contribute to salt tolerance, regulating uptake of $\mathrm{Na}^{+}$and $\mathrm{Cl}^{-}$from the soil is of primary importance, particularly in glycophytes which appear to have unidirectional $\mathrm{Na}^{+}$and $\mathrm{Cl}^{-}$influx that greatly exceeds net uptake [127]. Although several studies convincingly show that nonselective cation channels are involved, their molecular nature is largely unknown. Out of the substantial gene families that encode nonselective cation channels (CNGCs and GluRs), only CNGC3 and CNGC10 were shown to have a moderate impact on salt tolerance $[25,128]$. The data available suggest that single CNGCs do not play important roles in $\mathrm{Na}^{+}$uptake. However, creating multiple loss of function mutants, for example, for all CNGCs or GluRs expressed at the root periphery, may be required to provide more conclusive evidence in this respect. $\mathrm{Na}^{+}$efflux processes should be maximized to counteract $\mathrm{Na}^{+}$ influx. This might be possible by overexpressing $\mathrm{Na}^{+} / \mathrm{H}^{+}$ antiporters or $\mathrm{Na}^{+}$-ATPases specifically in the outer root cells to improve $\mathrm{Na}^{+}$extrusion. The bryophyte Physcomitrella patens is tolerant to a range of stresses and is consequently attracting significant attention as a potential source of genes to improve stress tolerance in higher plants [129-132]. As in many algae and fungi [133], and unlike higher plants that do not have primary ATP hydrolysing $\mathrm{Na}^{+}$pumps, $P$. patens has two $\mathrm{Na}^{+}$-ATPases: PpENA1 and PpENA2 [134]. Expression of PpENA1 is significantly upregulated by $\mathrm{Na}^{+}$stress, and the wild-type Physcomitrella maintained a higher $\mathrm{K}^{+} / \mathrm{Na}^{+}$ ratio and larger size than the enal knockout line at moderate $\mathrm{Na}^{+}$concentrations $(100 \mathrm{mM})$ [135]. The generation and characterization of plants with increased $\mathrm{Na}^{+}$efflux from the root epidermal and cortical cells are eagerly awaited. The potential for storage of $\mathrm{Na}^{+}$in vacuoles in the root should be maximized, as has been achieved by overexpression of NHX and vacuolar pyrophosphatase genes $[11,15]$. Loading of $\mathrm{Na}^{+}$into the xylem by the inner stelar cells of the root should be minimized and retrieval of $\mathrm{Na}^{+}$from the xylem increased, as has been achieved through amplification of AtHKT1;1 activity in the root stele in Arabidopsis [40]. Once $\mathrm{Na}^{+}$ has been transported to the shoot, strategies for tolerance to $\mathrm{Na}^{+}$become important. These include increased storage of $\mathrm{Na}^{+}$in the vacuole either through increased uptake or decreased efflux across the tonoplast. Several studies using overexpression of NHX and vacuolar pyrophosphatase have shown this strategy to be effective (Table 1) [11, 15, 9396, 98-100].

\section{Conclusion}

Several abiotic stresses cause changes in morphological, physiological, biochemical, and molecular processes in plants. The increasing prevalence of soil salinity is one of the most dangerous obstacles to improving crop productivity and quality. The adverse effects of saline soil include ion toxicity, nutrient constraints, osmotic stress, and oxidative stress. Many gene targets involved in salt tolerance have been identified through various approaches, particularly through transcriptomic studies. It is likely that such approaches generate many false positives [136], and this is born out by a lack of supporting evidence for an actual function in plant salinity tolerance. The accumulative data show importance of two particular classes of transporters: HKTs which function in both $\mathrm{Na}^{+}$uptake and long-distance translocation [47] and NHXs in their capacity as $\mathrm{Na}^{+}: \mathrm{H}^{+}$ antiport [137] or by maintaining $\mathrm{K}^{+}$homeostasis [138]. The significance of these systems is often isoform dependent and may be further complicated by allelic variation between cultivars. Manipulation of several of the genes discussed above has been shown to alter uptake, efflux, translocation, and compartmentation of $\mathrm{Na}^{+}$. Knowledge gained through use of heterologous expression systems and model plant systems provides an extremely useful starting point for the development of salinity-tolerant crop plants. However, further work involving the transgenic expression of $\mathrm{Na}^{+}$ transporters in cereal and broad leaved crop plants needs to be undertaken. Before any claims of salinity tolerance can be substantiated, robust data on yield measurements is required; preferably from field-based trials [139]. Also, it is argued that phenotyping of Arabidopsis should be carried out under the most relevant conditions possible, notably, under transpiring conditions rather than in sealed-agar-plate-based assays, as transpiration is a crucial factor in the transport of ions such as $\mathrm{Na}^{+}$through the plant.

\section{References}

[1] R. Munns, R. A. James, and A. Läuchli, "Approaches to increasing the salt tolerance of wheat and other cereals," Journal of Experimental Botany, vol. 57, no. 5, pp. 1025-1043, 2006.

[2] R. G. Alscher, J. L. Donahue, and C. L. Cramer, "Reactive oxygen species and antioxidants: relationships in green cells," Physiologia Plantarum, vol. 100, no. 2, pp. 224-233, 1997.

[3] R. Munns and M. Tester, "Mechanisms of salinity tolerance," Annual Review of Plant Biology, vol. 59, pp. 651-681, 2008.

[4] F. J. M. Maathuis and A. Amtmann, " $\mathrm{K}^{+}$nutrition and $\mathrm{Na}^{+}$ toxicity: the basis of cellular $\mathrm{K}^{+} / \mathrm{Na}^{+}$ratios," Annals of Botany, vol. 84, no. 2, pp. 123-133, 1999.

[5] J. K. Zhu, "Plant salt tolerance," Trends in Plant Science, vol. 6, no. 2, pp. 66-71, 2001. 
[6] J. A. Hernández, M. A. Ferrer, A. Jiménez, A. R. Barceló, and F. Sevilla, "Antioxidant systems and $\mathrm{O}_{2}{ }^{-}-\mathrm{H}_{2} \mathrm{O}_{2}$ production in the apoplast of pea leaves. Its relation with salt-induced necrotic lesions in minor veins," Plant Physiology, vol. 127, no. 3, pp. 817-831, 2001.

[7] D. Bartels and R. Sunkar, "Drought and salt tolerance in plants," Critical Reviews in Plant Sciences, vol. 24, no. 1, pp. 23-58, 2005.

[8] E. Blumwald, "Sodium transport and salt tolerance in plants," Current Opinion in Cell Biology, vol. 12, no. 4, pp. 431-434, 2000.

[9] T. J. Flowers and T. D. Colmer, "Salinity tolerance in halophytes," New Phytologist, vol. 179, no. 4, pp. 945-963, 2008.

[10] F. J. M. Maathuis, "Monovalent cation transporters; establishing a link between bioinformatics and physiology," Plant and Soil, vol. 301, no. 1-2, pp. 1-15, 2007.

[11] M. P. Apse, G. S. Aharon, W. A. Snedden, and E. Blumwald, "Salt tolerance conferred by overexpression of a vacuolar $\mathrm{Na}^{+} / \mathrm{H}^{+}$antiport in Arabidopsis," Science, vol. 285, no. 5431, pp. 1256-1258, 1999.

[12] D. P. Schachtman and J. I. Schroeder, "Structure and transport mechanism of a high-affinity potassium uptake transporter from higher plants," Nature, vol. 370, no. 6491, pp. 655-658, 1994.

[13] A. Rus, B. H. Lee, A. Muñoz-Mayor et al., "AtHKT1 facilitates $\mathrm{Na}^{+}$homeostasis and $\mathrm{K}^{+}$nutrition in planta," Plant Physiology, vol. 136, no. 1, pp. 2500-2511, 2004.

[14] J. K. Zhu, "Genetic analysis of plant salt tolerance using Arabidopsis," Plant Physiology, vol. 124, no. 3, pp. 941-948, 2000.

[15] R. A. Gaxiola, J. Li, S. Undurraga et al., "Drought- and salttolerant plants result from overexpression of the AVP1 $\mathrm{H}^{+}$pump," Proceedings of the National Academy of Sciences of the United States of America, vol. 98, no. 20, pp. 11444-11449, 2001.

[16] L. Xiong and J. K. Zhu, "Molecular and genetic aspects of plant responses to osmotic stress," Plant, Cell and Environment, vol. 25, no. 2, pp. 131-139, 2002.

[17] M. Tester and R. Davenport, " $\mathrm{Na}^{+}$tolerance and $\mathrm{Na}^{+}$ transport in higher plants," Annals of Botany, vol. 91, no. 5, pp. 503-527, 2003.

[18] T. Horie and J. I. Schroeder, "Sodium transporters in plants. Diverse genes and physiological functions," Plant Physiology, vol. 136, no. 1, pp. 2457-2462, 2004.

[19] Q. Leng, R. W. Mercier, B. G. Hua, H. Fromm, and G. A. Berkowitz, "Electrophysiological analysis of cloned cyclic nucleotide-gated ion channels," Plant Physiology, vol. 128, no. 2, pp. 400-410, 2002.

[20] V. Demidchik, P. A. Essah, and M. Tester, "Glutamate activates cation currents in the plasma membrane of Arabidopsis root cells," Planta, vol. 219, no. 1, pp. 167-175, 2004.

[21] F. J. M. Maathuis and D. Sanders, "Sodium uptake in Arabidopsis roots is regulated by cyclic nucleotides," Plant Physiology, vol. 127, no. 4, pp. 1617-1625, 2001.

[22] I. N. Talke, D. Blaudez, F. J. M. Maathuis, and D. Sanders, "CNGCs: prime targets of plant cyclic nucleotide signalling?" Trends in Plant Science, vol. 8, no. 6, pp. 286-293, 2003.

[23] C. Balagué, B. Lin, C. Alcon et al., "HLM1, an essential signaling component in the hypersensitive response, is a member of the cyclic nucleotide-gated channel ion channel family," Plant Cell, vol. 15, no. 2, pp. 365-379, 2003.
[24] J. Li, H. Yang, W. A. Peer et al., "Plant science: Arabidopsis $\mathrm{H}^{+}$PPase AVP1 regulates auxin-mediated organ development," Science, vol. 310, no. 5745, pp. 121-125, 2005.

[25] A. Gobert, G. Park, A. Amtmann, D. Sanders, and F. J. M. Maathuis, "Arabidopsis thaliana Cyclic Nucleotide Gated Channel 3 forms a non-selective ion transporter involved in germination and cation transport," Journal of Experimental Botany, vol. 57, no. 4, pp. 791-800, 2006.

[26] D. P. Schachtman, S. D. Tyerman, and B. R. Terry, "The $\mathrm{K}^{+} / \mathrm{Na}^{+}$selectivity of a cation channel in the plasma membrane of root cells does not differ in salt-tolerant and saltsensitive wheat species," Plant Physiology, vol. 97, no. 2, pp. 598-605, 1991.

[27] A. Amtmann and D. Sanders, "Mechanisms of $\mathrm{Na}^{+}$uptake by plant cells," Advances in Botanical Research, vol. 29, pp. 75$112,1998$.

[28] S. M. Wang, J. L. Zhang, and T. J. Flowers, "Low-affinity $\mathrm{Na}^{+}$ uptake in the Halophyte Suaeda maritima," Plant Physiology, vol. 145, no. 2, pp. 559-571, 2007.

[29] M. A. Kader and S. Lindberg, "Uptake of sodium in protoplasts of salt-sensitive and salt-tolerant cultivars of rice, Oryza sativa L. determined by the fluorescent dye SBFI," Journal of Experimental Botany, vol. 56, no. 422, pp. 31493158, 2005.

[30] R. Haro, M. A. Bañuelos, M. E. Senn, J. Barrero-Gil, and A. Rodríguez-Navarro, "HKT1 mediates sodium uniport in roots. Pitfalls in the expression of HKT1 in yeast," Plant Physiology, vol. 139, no. 3, pp. 1495-1506, 2005.

[31] T. Horie, F. Hauser, and J. I. Schroeder, "HKT transportermediated salinity resistance mechanisms in Arabidopsis and monocot crop plants," Trends in Plant Science, vol. 14, no. 12, pp. 660-668, 2009.

[32] X. Yao, T. Horie, S. Xue et al., "Differential sodium and potassium transport selectivities of the rice OsHKT2;1 and OsHKT2;2 transporters in plant cells," Plant Physiology, vol. 152, no. 1, pp. 341-355, 2010.

[33] P. A. Essah, R. Davenport, and M. Tester, "Sodium influx and accumulation in Arabidopsis," Plant Physiology, vol. 133, no. 1, pp. 307-318, 2003.

[34] Sunarpi, T. Horie, J. Motoda et al., "Enhanced salt tolerance mediated by AtHKT1 transporter-induced $\mathrm{Na}^{+}$unloading from xylem vessels to xylem parenchyma cells," Plant Journal, vol. 44, no. 6, pp. 928-938, 2005.

[35] V. Demidchik and F. J. M. Maathuis, "Physiological roles of nonselective cation channels in plants: from salt stress to signalling and development," New Phytologist, vol. 175, no. 3, pp. 387-404, 2007.

[36] J. M. Pardo, "Biotechnology of water and salinity stress tolerance," Current Opinion in Biotechnology, vol. 21, no. 2, pp. 185-196, 2010.

[37] P. Berthomieu, G. Conéjéro, A. Nublat et al., "Functional analysis of AtHKT1 in Arabidopsis shows that $\mathrm{Na}^{+}$recirculation by the phloem is crucial for salt tolerance," $E M B O$ Journal, vol. 22, no. 9, pp. 2004-2014, 2003.

[38] R. A. James, R. J. Davenport, and R. Munns, "Physiological characterization of two genes for $\mathrm{Na}^{+}$exclusion in durum wheat, Nax1 and Nax2," Plant Physiology, vol. 142, no. 4, pp. 1537-1547, 2006.

[39] R. J. Davenport, A. Muñoz-Mayor, D. Jha, P. A. Essah, A. Rus, and M. Tester, "The $\mathrm{Na}^{+}$transporter AtHKT1;1 controls retrieval of $\mathrm{Na}^{+}$from the xylem in Arabidopsis," Plant, Cell and Environment, vol. 30, no. 4, pp. 497-507, 2007. 
[40] I. S. Møller, M. Gilliham, D. Jha et al., "Shoot $\mathrm{Na}^{+}$exclusion and increased salinity tolerance engineered by cell typespecific alteration of $\mathrm{Na}^{+}$transport in Arabidopsis," Plant Cell, vol. 21, no. 7, pp. 2163-2178, 2009.

[41] M. P. Apse and E. Blumwald, " $\mathrm{Na}^{+}$transport in plants," FEBS Letters, vol. 581, no. 12, pp. 2247-2254, 2007.

[42] M. A. Kader, T. Seidel, D. Golldack, and S. Lindberg, "Expressions of OsHKT1, OsHKT2, and OsVHA are differentially regulated under $\mathrm{NaCl}$ stress in salt-sensitive and salt-tolerant rice (Oryza sativa L.) cultivars," Journal of Experimental Botany, vol. 57, no. 15, pp. 4257-4268, 2006.

[43] T. Horie, A. Costa, T. H. Kim et al., "Rice OsHKT2;1 transporter mediates large $\mathrm{Na}^{+}$influx component into $\mathrm{K}^{+}$starved roots for growth," EMBO Journal, vol. 26, no. 12, pp. 3003-3014, 2007.

[44] D. Golldack, H. Su, F. Quigley et al., "Characterization of a HKT-type transporter in rice as a general alkali cation transporter," Plant Journal, vol. 31, no. 4, pp. 529-542, 2002.

[45] B. Garciadeblás, M. E. Senn, M. A. Bañuelos, and A. Rodríguez-Navarro, "Sodium transport and HKT transporters: the rice model," Plant Journal, vol. 34, no. 6, pp. 788801, 2003.

[46] M. A. Bañuelos, R. Haro, A. Fraile-Escanciano, and A. Rodríguez-Navarro, "Effects of polylinker uATGs on the function of grass HKT1 transporters expressed in yeast cells," Plant and Cell Physiology, vol. 49, no. 7, pp. 1128-1132, 2008.

[47] Z. H. Ren, J. P. Gao, L. G. Li et al., "A rice quantitative trait locus for salt tolerance encodes a sodium transporter," Nature Genetics, vol. 37, no. 10, pp. 1141-1146, 2005.

[48] S. Huang, W. Spielmeyer, E. S. Lagudah et al., "A sodium transporter (HKT7) is a candidate for Nax1, a gene for salt tolerance in durum wheat," Plant Physiology, vol. 142, no. 4, pp. 1718-1727, 2006.

[49] C. S. Byrt, J. D. Platten, W. Spielmeyer et al., "HKT1;5-like cation transporters linked to $\mathrm{Na}^{+}$exclusion loci in wheat, Nax2 and Kna1," Plant Physiology, vol. 143, no. 4, pp. 19181928, 2007.

[50] H. X. Lin, M. Z. Zhu, M. Yano et al., "QTLs for $\mathrm{Na}^{+}$and $\mathrm{K}^{+}$ uptake of the shoots and roots controlling rice salt tolerance," Theoretical and Applied Genetics, vol. 108, no. 2, pp. 253-260, 2004.

[51] J. M. Pardo and F. J. Quintero, "Plants and sodium ions: keeping company with the enemy," Genome Biology, vol. 3, no. 6, article 1017, pp. 1017.1-1017.4, 2002.

[52] G. E. Santa-María, F. Rubio, J. Dubcovsky, and A. RodríguezNavarro, "The HAK1 gene of barley is a member of a large gene family and encodes a high-affinity potassium transporter," Plant Cell, vol. 9, no. 12, pp. 2281-2289, 1997.

[53] H. H. Fu and S. Luan, "AtKUP1: a dual-affinity $\mathrm{K}^{+}$transporter from Arabidopsis," Plant Cell, vol. 10, no. 1, pp. 63-73, 1998.

[54] D. Y. Chao, Y. H. Luo, M. Shi, D. Luo, and H. X. Lin, "Salt-responsive genes in rice revealed by cDNA microarray analysis," Cell Research, vol. 15, no. 10, pp. 796-810, 2005.

[55] H. Walia, C. Wilson, P. Condamine et al., "Comparative transcriptional profiling of two contrasting rice genotypes under salinity stress during the vegetative growth stage," Plant Physiology, vol. 139, no. 2, pp. 822-835, 2005.

[56] H. Walia, C. Wilson, P. Condamine, X. Liu, A. M. Ismail, and T. J. Close, "Large-scale expression profiling and physiological characterization of jasmonic acid-mediated adaptation of barley to salinity stress," Plant, Cell and Environment, vol. 30, no. 4, pp. 410-421, 2007.

[57] H. Su, D. Golldack, C. Zhao, and H. J. Bohnert, "The expression of HAK-Type $\mathrm{K}^{+}$transporters is regulated in response to salinity stress in common ice plant," Plant Physiology, vol. 129, no. 4, pp. 1482-1493, 2002.

[58] D. P. Schachtman, R. Kumar, J. I. Schroeder, and E. L. Marsh, "Molecular and functional characterization of a novel low-affinity cation transporter (LCT1) in higher plants," Proceedings of the National Academy of Sciences of the United States of America, vol. 94, no. 20, pp. 11079-11084, 1997.

[59] S. Clemens, D. M. Antosiewicz, J. M. Ward, D. P. Schachtman, and J. I. Schroeder, "The plant cDNA LCT1 mediates the uptake of calcium and cadmium in yeast," Proceedings of the National Academy of Sciences of the United States of America, vol. 95, no. 20, pp. 12043-12048, 1998.

[60] A. Amtmann, M. Fischer, E. L. Marsh, A. Stefanovic, D. Sanders, and D. P. Schachtman, "The wheat cDNA LCT1 generates hypersensitivity to sodium in a salt-sensitive yeast strain," Plant Physiology, vol. 126, no. 3, pp. 1061-1071, 2001.

[61] H. Marschner, Mineral Nutrition in Higher Plants, Academic Press, London, UK, 2nd edition, 1995.

[62] J. M. Colmenero-Flores, G. Martínez, G. Gamba et al., "Identification and functional characterization of cationchloride cotransporters in plants," Plant Journal, vol. 50, no. 2, pp. 278-292, 2007.

[63] M. Hechenberger, B. Schwappach, W. N. Fischer, W. B. Frommer, T. J. Jentsch, and K. Steinmeyer, "A family of putative chloride channels from Arabidopsis and functional complementation of a yeast strain with a CLC gene disruption," Journal of Biological Chemistry, vol. 271, no. 52, pp. 33632-33638, 1996.

[64] H. Barbier-Brygoo, M. Vinauger, J. Colcombet, G. Ephritikhine, J. M. Frachisse, and C. Maurel, "Anion channels in higher plants: functional characterization, molecular structure and physiological role," Biochimica et Biophysica Acta, vol. 1465, no. 1-2, pp. 199-218, 2000.

[65] D. Geelen, C. Lurin, D. Bouchez et al., "Disruption of putative anion channel gene AtCLC- $a$ in Arabidopsis suggests a role in the regulation of nitrate content," Plant Journal, vol. 21, no. 3, pp. 259-267, 2000.

[66] A. De Angeli, D. Monachello, G. Ephritikhine et al., "The nitrate/proton antiporter AtCLCa mediates nitrate accumulation in plant vacuoles," Nature, vol. 442, no. 7105, pp. 939942, 2006.

[67] J. V. D. Fecht-Bartenbach, M. Bogner, M. Krebs, Y. D. Stierhof, K. Schumacher, and U. Ludewig, "Function of the anion transporter AtCLC-d in the trans-Golgi network," Plant Journal, vol. 50, no. 3, pp. 466-474, 2007.

[68] C. J. Diédhiou and D. Golldack, "Salt-dependent regulation of chloride channel transcripts in rice," Plant Science, vol. 170, no. 4, pp. 793-800, 2006.

[69] J. Negi, O. Matsuda, T. Nagasawa et al., " $\mathrm{CO}_{2}$ regulator SLAC1 and its homologues are essential for anion homeostasis in plant cells," Nature, vol. 452, no. 7186, pp. 483-486, 2008.

[70] T. Vahisalu, H. Kollist, Y. F. Wang et al., "SLAC1 is required for plant guard cell S-type anion channel function in stomatal signalling," Nature, vol. 452, no. 7186, pp. 487-491, 2008.

[71] E. Blumwald, G. S. Aharon, and M. P. Apse, "Sodium transport in plant cells," Biochimica et Biophysica Acta, vol. 1465, no. 1-2, pp. 140-151, 2000. 
[72] E. Blumwald and R. J. Poole, " $\mathrm{Na}^{+} / \mathrm{H}^{+}$antiport in isolated tonoplast vesicles from storage tissue of Beta vulgaris," Plant Physiologyl, vol. 78, pp. 163-167, 1985.

[73] M. Staal, F. J. M. Maathuis, T. M. Elzenga, J. H. M. Odberbeek, and H. B. A. Prins, " $\mathrm{Na}^{+} / \mathrm{H}^{+}$antiport activity of the salt-tolerant Plantago maritime and the salt-sensitive Plantago media," Physiologia Plantarum, vol. 82, pp. 179-184, 1991.

[74] A. Katz, H. R. Kaback, and M. Avron, " $\mathrm{Na}^{+} / \mathrm{H}^{+}$antiport in isolated plasma membrane vesicles from the halotolerant alga Dunaliella salina," FEBS Letters, vol. 202, no. 1, pp. 141-144, 1986.

[75] D. T. Britto and H. J. Kronzucker, "Futile cycling at the plasma membrane: a hallmark of low-affinity nutrient transport," Trends in Plant Science, vol. 11, no. 11, pp. 529534, 2006.

[76] H. Shi, F. J. Quintero, J. M. Pardo, and J. K. Zhu, "The putative plasma membrane $\mathrm{Na}^{+} / \mathrm{H}^{+}$antiporter SOS1 controls long-distance $\mathrm{Na}^{+}$transport in plants," Plant Cell, vol. 14, no. 2, pp. 465-477, 2002.

[77] Q. S. Qiu, Y. Guo, M. A. Dietrich, K. S. Schumaker, and J. K. Zhu, "Regulation of SOS1, a plasma membrane $\mathrm{Na}^{+} / \mathrm{H}^{+}$ exchanger in Arabidopsis thaliana, by SOS2 and SOS3," Proceedings of the National Academy of Sciences of the United States of America, vol. 99, no. 12, pp. 8436-8441, 2002.

[78] J. M. Pardo, B. Cubero, E. O. Leidi, and F. J. Quintero, "Alkali cation exchangers: roles in cellular homeostasis and stress tolerance," Journal of Experimental Botany, vol. 57, no. 5, pp. 1181-1199, 2006.

[79] D. H. Oh, E. Leidi, Q. Zhang et al., "Loss of Halophytism by interference with SOS1 expression," Plant Physiology, vol. 151, no. 1, pp. 210-222, 2009.

[80] R. Olías, Z. Eljakaoui, J. Li et al., "The plasma membrane $\mathrm{Na}^{+} / \mathrm{H}^{+}$antiporter SOS1 is essential for salt tolerance in tomato and affects the partitioning of $\mathrm{Na}^{+}$between plant organs," Plant, Cell and Environment, vol. 32, no. 7, pp. 904 916, 2009.

[81] F. J. Quintero, M. Ohta, H. Shi, J. K. Zhu, and J. M. Pardo, "Reconstitution in yeast of the Arabidopsis SOS signaling pathway for $\mathrm{Na}^{+}$homeostasis," Proceedings of the National Academy of Sciences of the United States of America, vol. 99, no. 13, pp. 9061-9066, 2002.

[82] M. J. Sánchez-Barrena, S. Moreno-Pérez, I. Angulo, M. Martínez-Ripoll, and A. Albert, "The complex between SOS3 and SOS2 regulatory domain from Arabidopsis thaliana: cloning, expression, purification, crystallization and preliminary X-ray analysis," Acta Crystallographica Section F, vol. 63, no. 7, pp. 568-570, 2007.

[83] R. Quan, H. Lin, I. Mendoza et al., "SCABP8/CBL10, a putative calcium sensor, interacts with the protein kinase SOS2 to protect Arabidopsis shoots from salt stress," Plant Cell, vol. 19, no. 4, pp. 1415-1431, 2007.

[84] H. Lin, Y. Yang, R. Quan et al., "Phosphorylation of SOS3-like calcium binding protein8 by SOS2 protein kinase stabilizes their protein complex and regulates salt tolerance in Arabidopsis," Plant Cell, vol. 21, no. 5, pp. 1607-1619, 2009.

[85] O. Batistič, N. Sorek, S. Schültke, S. Yalovsky, and J. Kudla, "Dual fatty acyl modification determines the localization and plasma membrane targeting of CBL/CIPK $\mathrm{Ca}^{2+}$ signaling complexes in Arabidopsis," Plant Cell, vol. 20, no. 5, pp. 13461362, 2008.

[86] B. G. Kim, R. Waadt, Y. H. Cheong et al., "The calcium sensor CBL10 mediates salt tolerance by regulating ion homeostasis in Arabidopsis," Plant Journal, vol. 52, no. 3, pp. 473-484, 2007.

[87] Q. S. Qiu, Y. Guo, F. J. Quintero, J. M. Pardo, K. S. Schumaker, and J. K. Zhu, "Regulation of vacuolar $\mathrm{Na}^{+} / \mathrm{H}^{+}$exchange in Arabidopsis thaliana by the salt-overly-sensitive (SOS) pathway," Journal of Biological Chemistry, vol. 279, no. 1, pp. 207-215, 2004.

[88] G. Batelli, P. E. Verslues, F. Agius et al., "SOS2 promotes salt tolerance in part by interacting with the vacuolar $\mathrm{H}^{+}$ATPase and upregulating its transport activity," Molecular and Cellular Biology, vol. 27, no. 22, pp. 7781-7790, 2007.

[89] S. Yokoi, F. J. Quintero, B. Cubero et al., "Differential expression and function of Arabidopsis thaliana $\mathrm{NHX} \mathrm{Na} / \mathrm{H}^{+}$ antiporters in the salt stress response," Plant Journal, vol. 30, no. 5, pp. 529-539, 2002.

[90] R. An, Q. J. Chen, M. F. Chai et al., "AtNHX8, a member of the monovalent cation:proton antiporter-1 family in Arabidopsis thaliana, encodes a putative $\mathrm{Li}^{+} / \mathrm{H}^{+}$antiporter," Plant Journal, vol. 49, no. 4, pp. 718-728, 2007.

[91] H. T. Li, H. Liu, X. S. Gao, and H. Zhang, "Knock-out of Arabidopsis AtNHX4 gene enhances tolerance to salt stress," Biochemical and Biophysical Research Communications, vol. 382, no. 3, pp. 637-641, 2009.

[92] G. S. Aharon, M. P. Apse, S. Duan, X. Hua, and E. Blumwald, "Characterization of a family of vacuolar $\mathrm{Na}^{+} / \mathrm{H}^{+}$antiporters in Arabidopsis Thaliana," Plant and Soil, vol. 253, no. 1, pp. 245-256, 2003.

[93] H. X. Zhang and E. Blumwald, "Transgenic salt-tolerant tomato plants accumulate salt in foliage but not in fruit," Nature Biotechnology, vol. 19, no. 8, pp. 765-768, 2001.

[94] H. X. Zhang, J. N. Hodson, J. P. Williams, and E. Blumwald, "Engineering salt-tolerant Brassica plants: characterization of yield and seed oil quality in transgenic plants with increased vacuolar sodium accumulation," Proceedings of the National Academy of Sciences of the United States of America, vol. 98, no. 22, pp. 12832-12836, 2001.

[95] C. He, J. Yan, G. Shen et al., "Expression of an Arabidopsis vacuolar sodium/proton antiporter gene in cotton improves photosynthetic performance under salt conditions and increases fiber yield in the field," Plant and Cell Physiology, vol. 46, no. 11, pp. 1848-1854, 2005.

[96] F. Brini, M. Hanin, I. Mezghani, G. A. Berkowitz, and K. Masmoudi, "Overexpression of wheat $\mathrm{Na}^{+} / \mathrm{H}^{+}$antiporter TNHX1 and $\mathrm{H}^{+}$-pyrophosphatase TVP1 improve salt- and drought-stress tolerance in Arabidopsis thaliana plants," Journal of Experimental Botany, vol. 58, no. 2, pp. 301-308, 2007.

[97] A. Fukuda, A. Nakamura, A. Tagiri et al., "Function, intracellular localization and the importance in salt tolerance of a vacuolar $\mathrm{Na}^{+} / \mathrm{H}^{+}$antiporter from rice," Plant and Cell Physiology, vol. 45, no. 2, pp. 146-159, 2004.

[98] F. Y. Zhao, X. J. Zhang, P. H. Li, Y. X. Zhao, and H. Zhang, "Co-expression of the Suaeda salsa SsNHX1 and Arabidopsis AVP1 confer greater salt tolerance to transgenic rice than the single SsNHX1," Molecular Breeding, vol. 17, no. 4, pp. 341353, 2006.

[99] Z. Y. Xue, D. Y. Zhi, G. P. Xue, H. Zhang, Y. X. Zhao, and G. M. Xia, "Enhanced salt tolerance of transgenic wheat (Tritivum aestivum L.) expressing a vacuolar $\mathrm{Na}^{+} / \mathrm{H}^{+}$ antiporter gene with improved grain yields in saline soils in the field and a reduced level of leaf $\mathrm{Na}^{+}$," Plant Science, vol. 167, no. 4, pp. 849-859, 2004.

[100] A. Fukuda, K. Chiba, M. Maeda, A. Nakamura, M. Maeshima, and Y. Tanaka, "Effect of salt and osmotic 
stresses on the expression of genes for the vacuolar $\mathrm{H}^{+}$-pyrophosphatase, $\mathrm{H}^{+}$-ATPase subunit $\mathrm{A}$, and $\mathrm{Na}^{+} / \mathrm{H}^{+}$ antiporter from barley," Journal of Experimental Botany, vol. 55, no. 397, pp. 585-594, 2004.

[101] S. Fukada-Tanaka, Y. Inagaki, T. Yamaguchi, N. Saito, and S. Iida, "Colour-enhancing protein in blue petals," Nature, vol. 407, no. 6804, p. 581, 2000.

[102] K. Viehweger, B. Dordschbal, and W. Roos, "Elicitoractivated phospholipase $\mathrm{A}_{2}$ generates lysophosphatidylcholines that mobilize the vacuolar $\mathrm{H}^{+}$pool for $\mathrm{pH}$ signaling via the activation of $\mathrm{Na}^{+}$-dependent proton fluxes," Plant Cell, vol. 14, no. 7, pp. 1509-1525, 2002.

[103] T. Yamaguchi, M. P. Apse, H. Shi, and E. Blumwald, "Topological analysis of a plant vacuolar $\mathrm{Na}^{+} / \mathrm{H}^{+}$antiporter reveals a luminal $\mathrm{C}$ terminus that regulates antiporter cation selectivity," Proceedings of the National Academy of Sciences of the United States of America, vol. 100, no. 21, pp. 12510 12515, 2003.

[104] M. P. Apse, J. B. Sottosanto, and E. Blumwald, "Vacuolar cation $/ \mathrm{H}^{+}$exchange, ion homeostasis, and leaf development are altered in a T-DNA insertional mutant of AtNHX1, the Arabidopsis vacuolar $\mathrm{Na}^{+} / \mathrm{H}^{+}$antiporter," Plant Journal, vol. 36, no. 2, pp. 229-239, 2003.

[105] J. B. Sottosanto, A. Gelli, and E. Blumwald, "DNA array analyses of Arabidopsis thaliana lacking a vacuolar $\mathrm{Na}^{+} / \mathrm{H}^{+}$ antiporter: impact of AtNHX1 on gene expression," Plant Journal, vol. 40, no. 5, pp. 752-771, 2004.

[106] J. B. Sottosanto, Y. Saranga, and E. Blumwald, "Impact of AtNHX1, a vacuolar $\mathrm{Na}^{+} / \mathrm{H}^{+}$antiporter, upon gene expression during short- and long-term salt stress in Arabidopsis thaliana," BMC Plant Biology, vol. 7, article 18, 2007.

[107] M. Maeshima, "Vacuolar $\mathrm{H}^{+}$-pyrophosphatase," Biochimica et Biophysica Acta, vol. 1465, no. 1-2, pp. 37-51, 2000.

[108] M. Maeshima, "Tonoplast transporters: organization and function," Annual Review of Plant Biology, vol. 52, pp. 469497, 2001.

[109] P. Morsomme and M. Boutry, "The plant plasma membrane $\mathrm{H}^{+}$-ATPase: structure, function and regulation," Biochimica et Biophysica Acta, vol. 1465, no. 1-2, pp. 1-16, 2000.

[110] Y. M. Drozdowicz and P. A. Rea, "Vacuolar $\mathrm{H}^{+}$pyrophosphatases: from the evolutionary backwaters into the mainstream," Trends in Plant Science, vol. 6, no. 5, pp. 206-211, 2001.

[111] M. Hasegawa, R. Bressan, and J. M. Pardo, "The dawn of plant salt tolerance genetics," Trends in Plant Science, vol. 5, no. 8, pp. 317-319, 2000.

[112] Y. Sakakibara, H. Kobayashi, and K. Kasamo, "Isolation and characterization of cDNAs encoding vacuolar $\mathrm{H}^{+}$pyrophosphatase isoforms from rice (Oryza sativa L.)," Plant Molecular Biology, vol. 31, no. 5, pp. 1029-1038, 1996.

[113] Y. Tanaka, K. Chiba, M. Maeda, and M. Maeshima, "Molecular cloning of cDNA for vacuolar membrane protontranslocating inorganic pyrophosphatase in hordeum vulgare," Biochemical and Biophysical Research Communications, vol. 190, no. 3, pp. 1110-1114, 1993.

[114] F. Brini, R. A. Gaxiola, G. A. Berkowitz, and K. Masmoudi, "Cloning and characterization of a wheat vacuolar cation/proton antiporter and pyrophosphatase proton pump," Plant Physiology and Biochemistry, vol. 43, no. 4, pp. 347-354, 2005.

[115] A. Fukuda and Y. Tanaka, "Effects of ABA, auxin, and gibberellin on the expression of genes for vacuolar $\mathrm{H}^{+}$inorganic pyrophosphatase, $\mathrm{H}^{+}$-ATPase subunit $\mathrm{A}$, and
$\mathrm{Na}^{+} / \mathrm{H}^{+}$antiporter in barley," Plant Physiology and Biochemistry, vol. 44, no. 5-6, pp. 351-358, 2006.

[116] H. Yang, J. Knapp, P. Koirala et al., "Enhanced phosphorus nutrition in monocots and dicots over-expressing a phosphorus-responsive type $\mathrm{I} \mathrm{H}^{+}$-pyrophosphatase," Plant Biotechnology Journal, vol. 5, no. 6, pp. 735-745, 2007.

[117] G. Xu, H. Magen, J. Tarchitzky, and U. Kafkafi, "Advances in chloride nutrition of plants," Advances in Agronomy, vol. 68, pp. 97-150, 1999.

[118] C. J. Diédhiou, Mechanisms of salt tolerance: sodium, chloride and potassium homeostasis in two rice lines with different tolerance to salinity stress, Ph.D. thesis, University of Bielefeld, Bielefeld, Germany, 2006.

[119] A. Nakamura, A. Fukuda, S. Sakai, and Y. Tanaka, "Molecular cloning, functional expression and subcellular localization of two putative vacuolar voltage-gated chloride channels in rice (Oryza sativa L.)," Plant and Cell Physiology, vol. 47, no. 1, pp. 32-42, 2006.

[120] T. J. Flowers, P. F. Troke, and A. R. Yeo, "The mechanism of salt tolerance in halophytes," Annual Review of Plant Physiology, vol. 28, pp. 89-121, 1977.

[121] A. Lauchli, "Salt exclusion: an adaptation of legumes for crops and pastures under saline condition," in Salinity Tolerance in Plants: Strategies for Crop Improvement, R. C. Staples and G. H. Toennissen, Eds., pp. 171-187, Wiley, New York, NY, USA, 1984.

[122] D. Lacan and $\mathrm{M}$. Durand, " $\mathrm{Na}^{+}-\mathrm{K}^{+}$exchange at the xylem/symplast boundary: its significance in the salt sensitivity of soybean," Plant Physiology, vol. 110, no. 2, pp. 705-711, 1996.

[123] P. Mäser, B. Eckelman, R. Vaidyanathan et al., "Altered shoot/root $\mathrm{Na}^{+}$distribution and bifurcating salt sensitivity in Arabidopsis by genetic disruption of the $\mathrm{Na}^{+}$transporter AtHKT1," FEBS Letters, vol. 531, no. 2, pp. 157-161, 2002.

[124] R. Davenport, R. A. James, A. Zakrisson-Plogander, M. Tester, and R. Munns, "Control of sodium transport in durum wheat," Plant Physiology, vol. 137, no. 3, pp. 807-818, 2005.

[125] D. Hall, A. R. Evans, H. J. Newbury, and J. Pritchard, "Functional analysis of $C H X 21$ : a putative sodium transporter in Arabidopsis," Journal of Experimental Botany, vol. 57, no. 5, pp. 1201-1210, 2006.

[126] P. Senadheera, R. K. Singh, and F. J. M. Maathuis, "Differentially expressed membrane transporters in rice roots may contribute to cultivar dependent salt tolerance," Journal of Experimental Botany, vol. 60, no. 9, pp. 2553-2563, 2009.

[127] D. C. Plett and I. S. Møller, " $\mathrm{Na}^{+}$transport in glycophytic plants: what we know and would like to know," Plant, Cell and Environment, vol. 33, no. 4, pp. 612-626, 2010.

[128] K. M. Guo, O. Babourina, D. A. Christopher, T. Borsics, and $\mathrm{Z}$. Rengel, "The cyclic nucleotide-gated channel, AtCNGC10, influences salt tolerance in Arabidopsis," Physiologia Plantarum, vol. 134, no. 3, pp. 499-507, 2008.

[129] T. Nishiyama, T. Fujita, T. Shin-I et al., "Comparative genomics of Physcomitrella patens gametophytic transcriptome and Arabidopsis thaliana: implication for land plant evolution," Proceedings of the National Academy of Sciences of the United States of America, vol. 100, no. 13, pp. 8007-8012, 2003.

[130] W. Frank, D. Ratnadewi, and R. Reski, "Physcomitrella patens is highly tolerant against drought, salt and osmotic stress," Planta, vol. 220, no. 3, pp. 384-394, 2005.

[131] L. Saavedra, J. Svensson, V. Carballo, D. Izmendi, B. Welin, and S. Vidal, "A dehydrin gene in Physcomitrella patens is 
required for salt and osmotic stress tolerance," Plant Journal, vol. 45, no. 2, pp. 237-249, 2006.

[132] A. C. Cuming, S. H. Cho, Y. Kamisugi, H. Graham, and R. S. Quatrano, "Microarray analysis of transcriptional responses to abscisic acid and osmotic, salt, and drought stress in the moss, Physcomitrella patens," New Phytologist, vol. 176, no. 2, pp. 275-287, 2007.

[133] B. Garciadeblas, B. Benito, and A. Rodríguez-Navarro, "Plant cells express several stress calcium ATPases but apparently no sodium ATPase," Plant and Soil, vol. 235, no. 2, pp. 181-192, 2001.

[134] B. Benito and A. Rodríguez-Navarro, "Molecular cloning and characterization of a sodium-pump ATPase of the moss Physcomitrella patens," Plant Journal, vol. 36, no. 3, pp. 382 389, 2003.

[135] C. Lunde, D. P. Drew, A. K. Jacobs, and M. Tester, "Exclusion of $\mathrm{Na}^{+}$via sodium ATPase (PpENA1) ensures normal growth of Physcomitrella patens under moderate salt stress," Plant Physiology, vol. 144, no. 4, pp. 1786-1796, 2007.

[136] F. J. M. Maathuis, "The role of monovalent cation transporters in plant responses to salinity," Journal of Experimental Botany, vol. 57, no. 5, pp. 1137-1147, 2006.

[137] M. P. Apse and E. Blumwald, "Engineering salt tolerance in plants," Current Opinion in Biotechnology, vol. 13, no. 2, pp. 146-150, 2002.

[138] K. Venema, A. Belver, M. C. Marín-Manzano, M. P. Rodríguez-Rosales, and J. P. Donaire, "A novel intracellular $\mathrm{K}^{+} / \mathrm{H}^{+}$antiporter related to $\mathrm{Na}^{+} / \mathrm{H}^{+}$antiporters is important for $\mathrm{K}^{+}$ion homeostasis in plants," Journal of Biological Chemistry, vol. 278, no. 25, pp. 22453-22459, 2003.

[139] T. J. Flowers, "Improving crop salt tolerance," Journal of Experimental Botany, vol. 55, no. 396, pp. 307-319, 2004. 

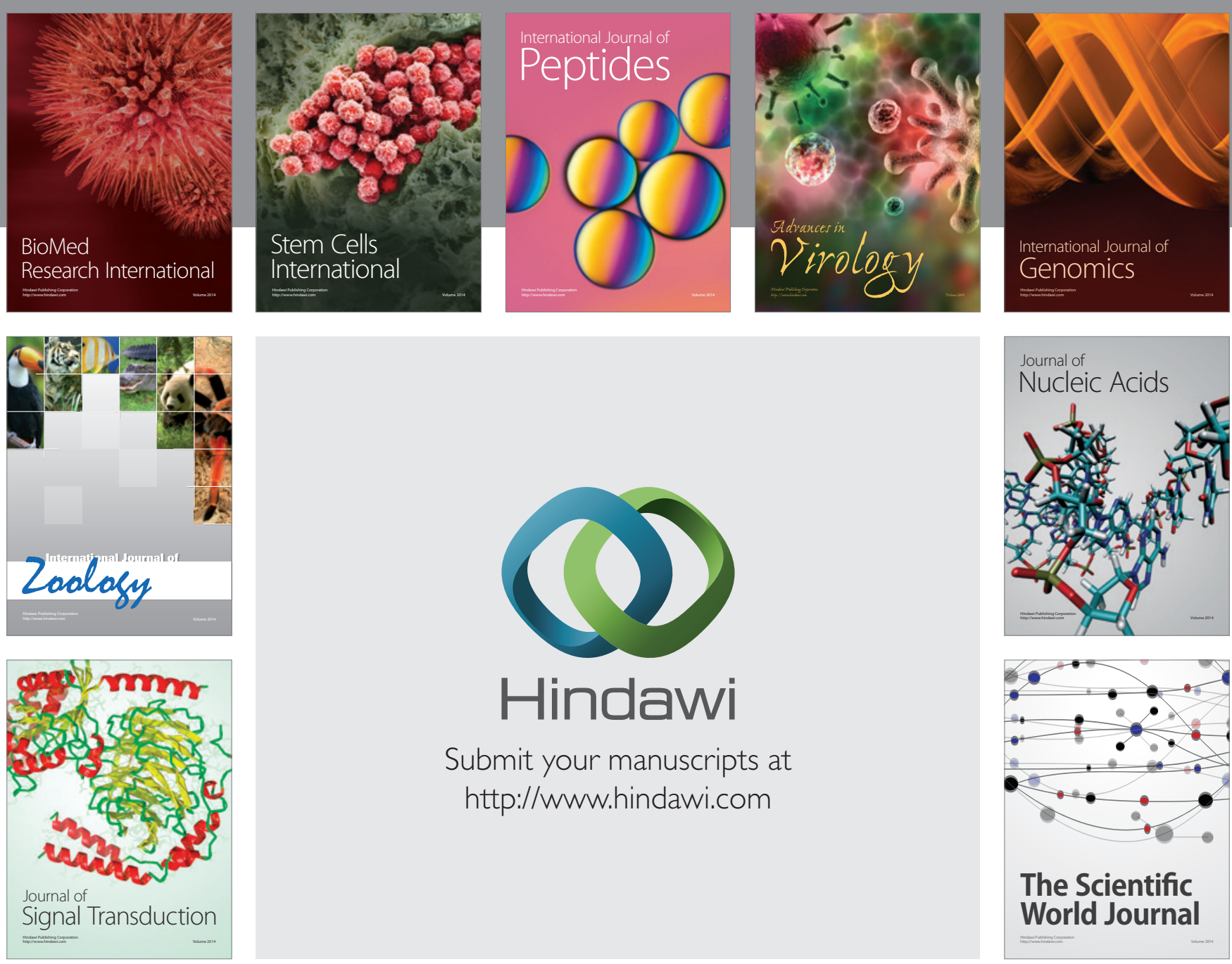

Submit your manuscripts at

http://www.hindawi.com
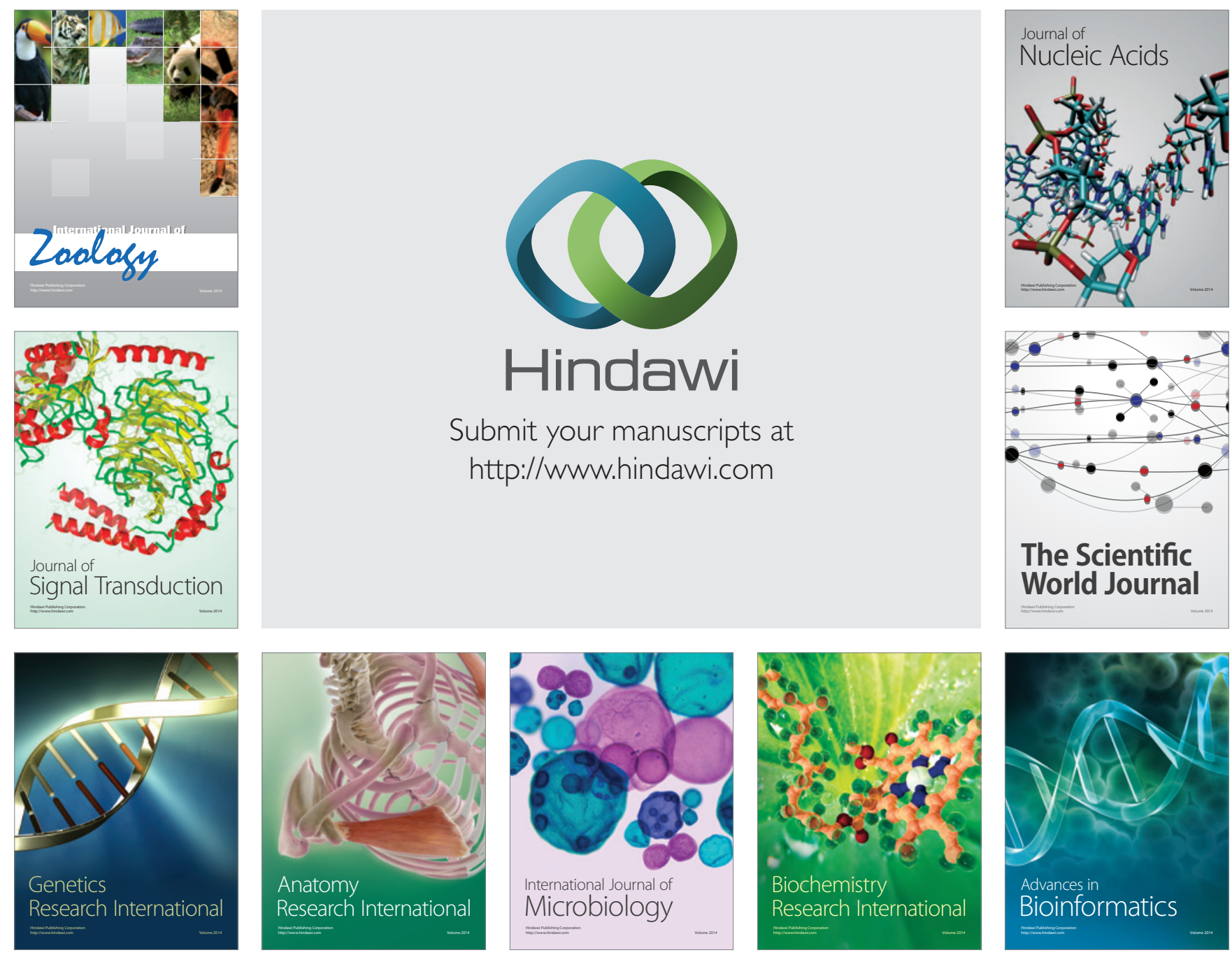

The Scientific World Journal
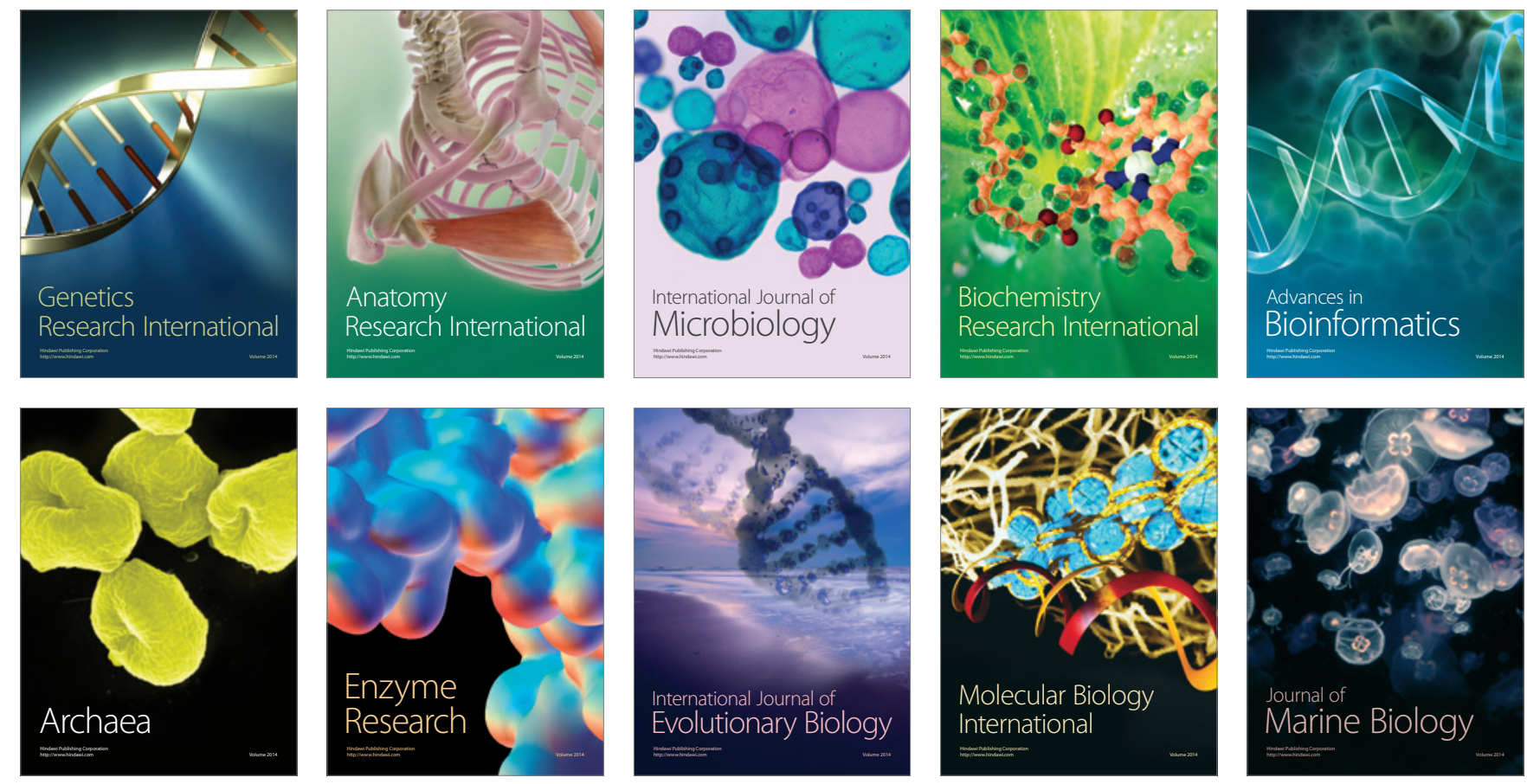